\title{
Nitrate radical generation via continuous generation of dinitrogen pentoxide in a laminar flow reactor coupled to an oxidation flow reactor
}

\author{
Andrew T. Lambe ${ }^{1}$, Ezra C. Wood $^{2}$, Jordan E. Krechmer ${ }^{1}$, Francesca Majluf ${ }^{1}$, Leah R. Williams ${ }^{1}$, Philip L. Croteau ${ }^{1}$, \\ Manuela Cirtog ${ }^{3}$, Anaïs Féron ${ }^{3}$, Jean-Eudes Petit ${ }^{4}$, Alexandre Albinet ${ }^{5}$, Jose L. Jimenez ${ }^{6}$, and Zhe Peng ${ }^{6}$ \\ ${ }^{1}$ Center for Aerosol and Cloud Chemistry, Aerodyne Research Inc., Billerica, MA, USA \\ ${ }^{2}$ Department of Chemistry, Drexel University, Philadelphia, PA, USA \\ ${ }^{3}$ Laboratoire Inter-Universitaire des Systèmes Atmosphériques (LISA), UMR CNRS 7583, Université Paris-Est-Créteil, \\ Université de Paris, Institut Pierre Simon Laplace (IPSL), Créteil, France \\ ${ }^{4}$ Laboratoire des Sciences du Climat et de l'Environnement (CNRS-CEA-UVSQ), \\ CEA Orme des Merisiers, Gif-sur-Yvette, France \\ ${ }^{5}$ Institut National de l'Environnement Industriel et des Risques (Ineris), Verneuil-en-Halatte, France \\ ${ }^{6}$ Department of Chemistry and Cooperative Institute for Research in Environmental Sciences (CIRES), \\ University of Colorado, Boulder, CO, USA
}

Correspondence: Andrew T. Lambe (lambe@ aerodyne.com) and Zhe Peng (zhe.peng@ colorado.edu)

Received: 5 December 2019 - Discussion started: 23 January 2020

Revised: 10 April 2020 - Accepted: 22 April 2020 - Published: 15 May 2020

\begin{abstract}
Oxidation flow reactors (OFRs) are an emerging tool for studying the formation and oxidative aging of organic aerosols and other applications. The majority of OFR studies to date have involved the generation of the hydroxyl radical $(\mathrm{OH})$ to mimic daytime oxidative aging processes. In contrast, the use of the nitrate radical $\left(\mathrm{NO}_{3}\right)$ in modern OFRs to mimic nighttime oxidative aging processes has been limited due to the complexity of conventional techniques that are used to generate $\mathrm{NO}_{3}$. Here, we present a new method that uses a laminar flow reactor (LFR) to continuously generate dinitrogen pentoxide $\left(\mathrm{N}_{2} \mathrm{O}_{5}\right)$ in the gas phase at room temperature from the $\mathrm{NO}_{2}+\mathrm{O}_{3}$ and $\mathrm{NO}_{2}+\mathrm{NO}_{3}$ reactions. The $\mathrm{N}_{2} \mathrm{O}_{5}$ is then injected into a dark Potential Aerosol Mass (PAM) OFR and decomposes to generate $\mathrm{NO}_{3}$; hereafter, this method is referred to as "OFR-i $\mathrm{N}_{2} \mathrm{O}_{5}$ " (where "i" stands for "injected"). To assess the applicability of the OFR-iN $\mathrm{O}_{5}$ method towards different chemical systems, we present experimental and model characterization of the integrated $\mathrm{NO}_{3}$ exposure, $\mathrm{NO}_{3}: \mathrm{O}_{3}, \mathrm{NO}_{2}: \mathrm{NO}_{3}$, and $\mathrm{NO}_{2}: \mathrm{O}_{2}$ as a function of LFR and OFR conditions. These parameters were used to investigate the fate of representative organic peroxy radicals $\left(\mathrm{RO}_{2}\right)$ and aromatic alkyl radicals generated from volatile organic compound (VOC) $+\mathrm{NO}_{3}$ reactions, and VOCs that
\end{abstract}

are reactive towards both $\mathrm{O}_{3}$ and $\mathrm{NO}_{3}$. Finally, we demonstrate the OFR-i $\mathrm{N}_{2} \mathrm{O}_{5}$ method by generating and characterizing secondary organic aerosol from the $\beta$-pinene $+\mathrm{NO}_{3}$ reaction.

\section{Introduction}

The importance of nitrate radicals $\left(\mathrm{NO}_{3}\right)$ as a nighttime oxidant is well established (Wayne et al., 1991; Brown and Stutz, 2012; $\mathrm{Ng}$ et al., 2017). In the atmosphere, $\mathrm{NO}_{2}+\mathrm{O}_{3}$ is the primary source of $\mathrm{NO}_{3}$, after which $\mathrm{NO}_{3}$ exists in equilibrium with $\mathrm{NO}_{2}$ and $\mathrm{N}_{2} \mathrm{O}_{5}$. Atmospheric nighttime $\mathrm{NO}_{3}$ mixing ratios can vary by at least 2 orders of magnitude, ranging from $1 \mathrm{ppt}$ or less in remote areas to $10-400 \mathrm{ppt}$ in polluted urban regions (Finlayson-Pitts and Pitts Jr., 2000; Asaf et al., 2010; Warneck and Williams, 2012; Ng et al., 2017). Atmospheric organic compounds that are reactive towards $\mathrm{NO}_{3}$ include isoprene and monoterpenes that are emitted from biogenic sources (including urban vegetation), phenols and methoxyphenols emitted from biomass burning, and polycyclic aromatic hydrocarbons (PAHs) emitted from combustion processes. $\mathrm{NO}_{3}$ oxidation of these compounds 
generates oxygenated volatile organic compounds (OVOCs) and/or secondary organic aerosol (SOA), including particulate organic nitrates or nitroaromatics. The importance of these sources and processes are likely to continue to increase for the foreseeable future due to climate change (Melaas et al., 2016; Short, 2017).

Laboratory studies have attempted to elucidate the mechanisms associated with $\mathrm{NO}_{3}$-initiated oxidative aging processes in the gas and condensed phases and in environmental chambers and flow tubes. Traditional $\mathrm{NO}_{3}$ generation techniques typically utilize $\mathrm{N}_{2} \mathrm{O}_{5}$ as the radical precursor. $\mathrm{N}_{2} \mathrm{O}_{5}$ is generated from the reaction $\mathrm{NO}+\mathrm{O}_{3} \rightarrow \mathrm{NO}_{2}+\mathrm{O}_{2}$, followed by the reactions $\mathrm{NO}_{2}+\mathrm{O}_{3} \rightarrow \mathrm{NO}_{3}+\mathrm{O}_{2}$ and $\mathrm{NO}_{2}+$ $\mathrm{NO}_{3} \rightarrow \mathrm{N}_{2} \mathrm{O}_{5}$. The synthesized $\mathrm{N}_{2} \mathrm{O}_{5}$ is collected and stored in a cold trap under dry conditions to minimize hydrolysis of $\mathrm{N}_{2} \mathrm{O}_{5}$ to nitric acid $\left(\mathrm{HNO}_{3}\right)$. This method has limitations that hinder widespread usage: specifically, long-term storage and handling of $\mathrm{N}_{2} \mathrm{O}_{5}$ at low temperature and under dry conditions is difficult, and the continuous generation of $\mathrm{N}_{2} \mathrm{O}_{5}$ that is required for oxidation flow reactors (OFRs) or other continuous flow chambers is challenging. Thus, field studies investigating the $\mathrm{NO}_{3}$-induced $\mathrm{SOA}$ formation potential of ambient air are extremely limited (Palm et al., 2017). Alternative $\mathrm{NO}_{3}$ generation techniques that utilize reactions between chlorine atoms and chlorine nitrate $\left(\mathrm{ClONO}_{2}\right)$ or fluorine atoms and $\mathrm{HNO}_{3}$ require cold storage of $\mathrm{ClONO}_{2}$ and handling or generation of halogen species that are reactive towards organic compounds (Burrows et al., 1985).

To address issues associated with traditional $\mathrm{NO}_{3}$ generation techniques, we developed and characterized a new method that is well suited to applications where a continuous source of $\mathrm{N}_{2} \mathrm{O}_{5}$ and $\mathrm{NO}_{3}$ is required, such as OFR studies. The method is capable of continuous $\mathrm{N}_{2} \mathrm{O}_{5}$ generation in the gas phase at room temperature using a laminar flow reactor (LFR) that is coupled to a dark OFR. $\mathrm{N}_{2} \mathrm{O}_{5}$ injected into the OFR decomposes to generate $\mathrm{NO}_{3}$ and initiate oxidation of reactive VOCs. Hereafter, we refer to this method as "OFR-i $\mathrm{N}_{2} \mathrm{O}_{5}$ " (where "i" stands for "injected"). We present experimental and model characterization of OFR- $\mathrm{iN}_{2} \mathrm{O}_{5}$ as a function of LFR and OFR conditions, and we demonstrate the application of OFR-i $\mathrm{N}_{2} \mathrm{O}_{5}$ to generate and characterize SOA from the $\beta$-pinene $+\mathrm{NO}_{3}$ reaction.

\section{Methods}

\section{$2.1 \quad \mathrm{~N}_{2} \mathrm{O}_{5}$ and $\mathrm{NO}_{3}$ generation}

Figure 1 shows a process flow diagram of the OFR-i $\mathrm{N}_{2} \mathrm{O}_{5}$ method. Separate flows containing $\mathrm{NO}_{2}$ and $\mathrm{O}_{3}$ were input to a perfluoroalkoxy (PFA) tube with a $2.54 \mathrm{~cm}$ o.d. (outer diameter), a $2.22 \mathrm{~cm}$ i.d. (inner diameter), and a $152.4 \mathrm{~cm}$ length that was operated as an LFR. Previous studies used a similar process to generate $\mathrm{N}_{2} \mathrm{O}_{5}$ (Wood et al., 2003; Boyd et al., 2015), although the LFR materials, flow rates,

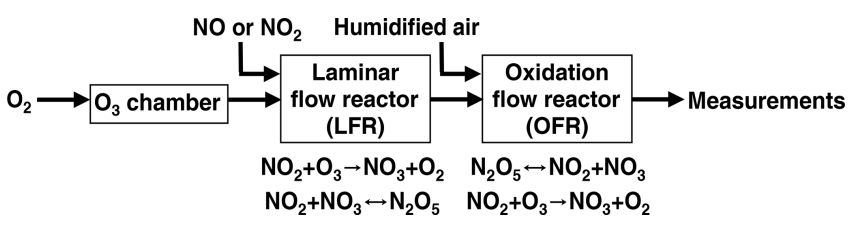

Figure 1. Process flow diagram of the OFR-i $\mathrm{N}_{2} \mathrm{O}_{5}$ technique used to generate nitrate radicals $\left(\mathrm{NO}_{3}\right)$.

and reagent concentrations were different. A compressed gas cylinder containing $1.00 \pm 0.02 \% \mathrm{NO}_{2}$ in $\mathrm{N}_{2}$ (Praxair) was used to supply $\mathrm{NO}_{2}$. While not used for this study, replacing $\mathrm{NO}_{2}$ with $\mathrm{NO}$ to avoid $\mathrm{NO}_{2}$-to- $\mathrm{HNO}_{3}$ conversion inside the gas cylinder and increasing $\left[\mathrm{O}_{3}\right]$ accordingly achieves similar results. $\mathrm{O}_{3}$ was generated by passing $1750-$ $1800 \mathrm{~cm}^{3} \mathrm{~min}^{-1}$ of pure $\mathrm{O}_{2}$ through a custom $\mathrm{O}_{3}$ chamber housing a mercury fluorescent lamp (GPH212T5VH, Light Sources, Inc.) or $500-1800 \mathrm{~cm}^{3} \mathrm{~min}^{-1} \mathrm{O}_{2}$ through a corona discharge ozone generator (Enaly $1 \mathrm{KNT}$ ). We used $1800 \mathrm{~cm}^{3} \mathrm{~min}^{-1}$ of $\mathrm{O}_{2}$ carrier gas flow through the LFR ( $R e \sim 110$, i.e., laminar flow) to achieve $\tau_{\mathrm{LFR}}=20 \mathrm{~s}$ for reasons that are discussed in Sect. 3.1. The $\mathrm{NO}_{2}$ mixing ratio entering the LFR, $\left[\mathrm{NO}_{2}\right]_{0}$, LFR, was calculated from the $\mathrm{NO}_{2}$ mixing ratio in the compressed gas mixture and the dilution ratio of $0-50$ or $0-1300 \mathrm{~cm}^{3} \mathrm{~min}^{-1}$ gas flow into $\mathrm{O}_{2}$ which was controlled using mass flow controllers. The $\mathrm{O}_{3}$ mixing ratio entering the LFR, $\left[\mathrm{O}_{3}\right]_{0, \mathrm{LFR}}$, was measured using a 2B Technologies 106-MFT or a Teledyne M452 flowthrough $\mathrm{O}_{3}$ analyzer when generated from the mercury lamp or corona discharge source, respectively. The output of the LFR was mixed with a carrier gas containing $3.8 \mathrm{~L} \mathrm{~min}^{-1}$ synthetic air and then injected into a Potential Aerosol Mass (PAM) OFR (Aerodyne Research, Inc.), which is a horizontal 13.3 L aluminum cylindrical chamber operated in continuous flow mode (Kang et al., 2007; Lambe et al., 2011, 2019) with $6.5 \mathrm{~L} \mathrm{~min}^{-1}$ flow through the reactor. The mean residence time in the OFR $\left(\tau_{\mathrm{OFR}}\right)$ was $120 \pm 34 \mathrm{~s}( \pm 1 \sigma)$, as obtained from measurements of $10 \mathrm{~s}$ pulsed inputs of $\mathrm{NO}_{2}$ to the OFR obtained using a 2B Technologies Model $405 \mathrm{NO}_{x}$ analyzer (Fig. S1). Across all experiments, the relative humidity in the OFR $\left(\mathrm{RH}_{\mathrm{OFR}}\right)$ was controlled in the range of $7 \%-85 \%$ at $23-25^{\circ} \mathrm{C}$ by passing the carrier gas through a Nafion humidifier (Perma Pure LLC) or heated recirculating water bath (NESLAB Instruments, Inc.) prior to mixing with the LFR outflow. The $\mathrm{O}_{3}$ mixing ratio at the exit of the OFR was measured with a 2B Technologies Model 106-M ozone analyzer.

\subsubsection{OFR-iN $\mathrm{O}_{5}$ characterization studies}

In one set of experiments, the integrated $\mathrm{NO}_{3}$ exposure $\left(\mathrm{NO}_{3}\right.$ exp $)$, defined here as the product of the average $\mathrm{NO}_{3}$ concentration and $\tau_{\mathrm{OFR}}$, was characterized by measuring the decay of VOC tracers reactive towards $\mathrm{NO}_{3}$ using 
a Tofwerk/Aerodyne Vocus proton transfer reaction timeof-flight mass spectrometer (PTR-MS; Krechmer et al., 2018). For this purpose, the tracer decay method is advantageous to direct $\mathrm{NO}_{3}$ measurements at the OFR inlet and/or outlet, because potential $\mathrm{NO}_{3}$ concentration gradients inside the OFR that might otherwise bias $\mathrm{NO}_{3}$ exp are accounted for. Tracers that were liquid at room temperature were injected into the OFR through a $10.2 \mathrm{~cm}$ length of $0.0152 \mathrm{~cm}$ i.d. Teflon tubing at a liquid flow rate of about $0.94 \mu \mathrm{Lh}^{-1}$ using a syringe pump, prior to evaporation into a $2.4 \mathrm{~L} \mathrm{~min}^{-1} \mathrm{~N}_{2}$ carrier gas. In preliminary studies, tracers such as isoprene and $\beta$-pinene were too reactive towards $\mathrm{NO}_{3}$ to facilitate accurate characterization of $\mathrm{NO}_{3}$ exp over the majority of the OFR-iN $\mathrm{O}_{5}$ conditions that were investigated. Thus, experiments described in this paper used mixtures of tracers with bimolecular $k_{\mathrm{NO}_{3}}$ ranging from approximately $10^{-16}$ to $10^{-13} \mathrm{~cm}^{3}$ molecules ${ }^{-1} \mathrm{~s}^{-1}$ and $k_{\mathrm{O}_{3}}<10^{-19} \mathrm{~cm}^{3}$ molecules ${ }^{-1} \mathrm{~s}^{-1}$ (Table S1). Acetonitrile was used as a nonreactive tracer. In "low $\mathrm{O}_{3}$ " experiments $\left(\left[\mathrm{O}_{3}\right]_{0, \mathrm{LFR}}=10\right.$ to $\left.300 \mathrm{ppm}\right)$ a mixture of acetonitrile, butanal, thiophene, 2,3-dihydrobenzofuran, and naphthalene- $\mathrm{d}_{8}\left(\mathrm{C}_{10} \mathrm{D}_{8}\right)$, each with mixing ratios of approximately $660,50,56,40$, and $18 \mathrm{ppb}$, respectively, was used. For this tracer mixture, the total external $\mathrm{NO}_{3}$ reactivity $\left(\mathrm{NO}_{3} \mathrm{R}_{\text {ext }}\right)$, which is the summed product of each tracer mixing ratio and its $\mathrm{NO}_{3}$ rate constant, was approximately $0.07 \mathrm{~s}^{-1}$. Naphthalene- $\mathrm{d}_{8}$ was introduced by flowing $5 \mathrm{~cm}^{3} \mathrm{~min}^{-1} \mathrm{~N}_{2}$ through a Teflon tube packed with solid $\mathrm{C}_{10} \mathrm{D}_{8}$. In "high $\mathrm{O}_{3}$ " experiments $\left(\left[\mathrm{O}_{3}\right]_{0, \mathrm{LFR}}=6100\right.$ to $7400 \mathrm{ppm}$ ), which generated higher $\mathrm{NO}_{3}$ exp, a mixture of acetonitrile (275 ppb), toluene (45 ppb), o-xylene (40 ppb), p-cymene (31 ppb), 1, 2, 4-trimethylbenzene (35 ppb), 1butanol (53 ppb), benzaldehyde (47 ppb), butanal (53 ppb), and thiophene (56 ppb) was used, with $\mathrm{NO}_{3} \mathrm{R}_{\text {ext }} \approx 0.38 \mathrm{~s}^{-1}$.

In another set of experiments that were conducted as part of the Aerosol Chemical Monitor Calibration Center (ACMCC) particulate organonitrates $(p \mathrm{ON})$ experiment (Albinet et al., 2019), direct measurements of $\mathrm{NO}_{3}$ generated via OFR-i $\mathrm{N}_{2} \mathrm{O}_{5}$ were performed using a newly developed "incoherent broad band cavity enhanced absorption spectroscopy" (IBBCEAS) technique (Cirtog et al., 2020; Fouqueau et al., 2020). The IBBCEAS instrument that was used measured absorption as a function of wavelength between $\lambda=640$ and $680 \mathrm{~nm}$, thereby allowing simultaneous measurements of $\mathrm{NO}_{2}$ and $\mathrm{O}_{3}$ along with $\mathrm{NO}_{3}$. During this experiment, $p \mathrm{ON}$ were generated in a PAM OFR that used $\left[\mathrm{O}_{3}\right]_{0, \mathrm{LFR}}=150$ $160 \mathrm{ppm}$ and $\left[\mathrm{NO}_{2}\right]_{0, \mathrm{LFR}}:\left[\mathrm{O}_{3}\right]_{0, \mathrm{LFR}}=0.75,1.0$, and 2.0 . IBBCEAS has been used to measure trace $\mathrm{NO}_{3}$ levels in laboratory and field studies (Venables et al., 2006; Kennedy et al., 2011) utilizing measurement principles that are described in detail by Fiedler et al. (2003) and Langridge et al. (2008). Briefly, measurements were conducted by exciting a high-finesse optical cavity formed by two high reflectivity mirrors with an incoherent broadband source centered on the $\lambda=662 \mathrm{~nm}$ absorption cross section of $\mathrm{NO}_{3}\left(2 \times 10^{-17} \mathrm{~cm}^{2}\right.$,
Orphal et al., 2003). Photons resonate between the two mirrors, allowing an effective path length of up to $4.5 \mathrm{~km}$ inside the cavity. The absorption coefficient of the sample in the cavity, $\alpha(\lambda)$, was calculated using Eq. (1):

$\alpha(\lambda)=\left(\frac{I_{0}(\lambda)}{I(\lambda)}-1\right)\left(\frac{1-R(\lambda)}{d}\right)$

where $\alpha(\lambda)$ is the absorption coefficient of the OFR sample in the instrument, $I(\lambda)$ and $I_{0}(\lambda)$ were the measured transmitted intensities in the presence and absence of the sample, $d=61 \mathrm{~cm}$ was the distance between the cavity mirrors, and $R(\lambda)$ was the mirror reflectivity $(\sim 99.98 \%) . I_{0}(\lambda)$ was obtained by stopping the OFR sample through the instrument and flowing nitrogen from a cylinder (Air Liquide). A period of at least $30 \mathrm{~s}$ was allowed between the measurement of $I_{0}(\lambda)$ and $I(\lambda)$ to ensure the complete purge of the instrument. $R(\lambda)$ was measured before each experiment using a certified calibration cylinder containing $600 \mathrm{ppb} \mathrm{NO}_{2}$ in zero air (Air Liquide). Concentrations were calculated by applying a least square fit to the measured $\alpha(\lambda)$ considering the absorbing species in the sample:

$\alpha(\lambda)=\left[\mathrm{NO}_{2}\right] \sigma_{\mathrm{NO}_{2}}+\left[\mathrm{NO}_{3}\right] \sigma_{\mathrm{NO}_{3}}+\left[\mathrm{O}_{3}\right] \sigma_{\mathrm{O}_{3}}+p(\lambda)$

where $\mathrm{NO}_{2}, \mathrm{NO}_{3}$, and $\mathrm{O}_{3}$ are the species absorbing in the spectral region of the instrument, $\alpha(\lambda)$ represents the respective absorption cross sections convoluted with the apparatus function (Vandaele et al., 1998; Voigt et al., 2001; Orphal et al., 2003), and $p(\lambda)$ represents a cubic polynomial to correct baseline deformations due to small LED intensity variations. To avoid saturation of the IBBCEAS in these experiments, the OFR sample was diluted by a controlled dilution factor ranging from 9 to 41, and the detection response was deliberately lowered by reducing the optical path length. The sampling line and optical cavity were made of PFA. The residence time in the IBBCEAS sampling line and instrument ranged from 8.3 to $21.8 \mathrm{~s}$. At these residence times, the calculated transmission efficiencies of $\mathrm{NO}_{3}$ from the OFR to the IBBCEAS ranged from $0.3 \%$ to $11 \%$, assuming a $\mathrm{NO}_{3}$ wall loss rate constant of $0.27 \mathrm{~s}^{-1}$ (Kennedy et al., 2011). Corrections to measured $\mathrm{NO}_{3}$ and $\mathrm{NO}_{2}$ values accounting for $\mathrm{N}_{2} \mathrm{O}_{5}$ thermal decomposition and sample dilution were applied to the IBBCEAS results presented in this paper.

To demonstrate the application of OFR $-\mathrm{iN}_{2} \mathrm{O}_{5}$ to generate SOA, the chemical composition and mass concentration of $\beta$-pinene $+\mathrm{NO}_{3}$ condensed-phase oxidation products was measured with an Aerodyne long-time-of-flight aerosol mass spectrometer (L-ToF-AMS) and/or an aerosol chemical speciation monitor (ACSM). A syringe pump was used to deliver $\beta$-pinene $(10 \%, v / v$, in carbon tetrachloride or $50 \%, v / v$, in ethanol) into the carrier gas flow at liquid flow rates ranging from 0.94 to $19 \mu \mathrm{Lh}^{-1}$. Results presented in this paper assume an AMS or ACSM collection efficiency of 0.5 (Middlebrook et al., 2012) and a relative ionization efficiency of particulate organics equal to 1.6 (Xu et al., 2018). 


\subsection{Photochemical model}

We used the KinSim chemical kinetic solver to calculate concentrations of radical and oxidant species (Peng et al., 2015; Peng and Jimenez, 2017, 2019). The KinSim mechanism shown in Table $\mathrm{S} 2$ was adapted from Palm et al. (2017) to model $\mathrm{NO}_{3}$ and $\mathrm{N}_{2} \mathrm{O}_{5}$ concentrations in the LFR and OFR. Inputs to the LFR-KinSim model were $\left[\mathrm{O}_{3}\right]_{0, \mathrm{LFR}}$, $\left[\mathrm{NO}_{2}\right]_{0, \mathrm{LFR}}, \mathrm{RH}=1 \%, T=24^{\circ} \mathrm{C}, \tau_{\mathrm{LFR}}=20 \mathrm{~s}$ (modeled as plug flow, see Sect. 3.1), and first-order wall loss rates of $\mathrm{NO}_{3}$ and $\mathrm{N}_{2} \mathrm{O}_{5}\left(k_{\mathrm{W}_{\mathrm{LFR}}, \mathrm{NO}_{3}}\right.$ and $\left.k_{\mathrm{W}_{\mathrm{LFR}}, \mathrm{N}_{2} \mathrm{O}_{5}}\right)$. Inputs to the OFR-KinSim model were $\left[\mathrm{O}_{3}\right],\left[\mathrm{NO}_{2}\right],\left[\mathrm{NO}_{3}\right]$, and $\left[\mathrm{N}_{2} \mathrm{O}_{5}\right]$ output from the LFR scaled by a measured dilution factor of 4.4; RH and $T$ measured in the OFR; $\tau_{\mathrm{OFR}}=120 \mathrm{~s}$, $k_{\mathrm{w}_{\mathrm{OFR}}, \mathrm{NO}_{3}}$, and $k_{\mathrm{w}_{\mathrm{OFR}}, \mathrm{N}_{2} \mathrm{O}_{5}}$; and input VOC tracer concentrations and their $k_{\mathrm{NO}_{3}}$ values. Because the calculated $\mathrm{N}_{2} \mathrm{O}_{5}$ residence time in the OFR inlet $(\sim 0.04 \mathrm{~s})$ was short compared with the $\mathrm{N}_{2} \mathrm{O}_{5}$ decomposition timescale at $T=23-25^{\circ} \mathrm{C}$ ( $\sim 20 \mathrm{~s}$ ), potential thermal decomposition of $\mathrm{N}_{2} \mathrm{O}_{5}$ during the dilution step was not considered in the model.

\subsubsection{LFR and OFR $k_{\mathrm{w}, \mathrm{NO}_{3}}$ and $k_{\mathrm{w}}, \mathrm{N}_{2} \mathrm{O}_{5}$ values}

Published $k_{\mathrm{W}, \mathrm{NO}_{3}}$ values onto tubing with a $1 \mathrm{~cm}$ (Teflon) and a $4 \mathrm{~cm}$ (Pyrex) i.d. are 0.2 and $0.1 \mathrm{~s}^{-1}$, respectively (Dubé et al., 2006; Wood et al., 2003), which bound the $2.22 \mathrm{~cm}$ i.d. of the LFR used in this study. Assuming $k_{\mathrm{w}}$ is inversely proportional to the internal diameter of the tube, we assumed $k_{\mathrm{w}_{\mathrm{LFR}}, \mathrm{NO}_{3}}=0.15 \mathrm{~s}^{-1}$. Extrapolating this value to the OFR (20.32 cm i.d.) yielded $k_{\mathrm{WOFR}}, \mathrm{NO}_{3}=0.02 \mathrm{~s}^{-1}$. At fixed OFR$\mathrm{iN}_{2} \mathrm{O}_{5}$ conditions that are summarized in Table S3, varying $k_{\mathrm{WLFR}}, \mathrm{NO}_{3}$ between 0 and $0.3 \mathrm{~s}^{-1}$ changed the $\mathrm{NO}_{3}$ exp achieved in the OFR by $0.3 \%$. Results were even less sensitive to the $k_{\mathrm{W}_{\mathrm{OFR}}, \mathrm{NO}_{3}}$ assumed for the OFR because of its larger diameter and higher $\mathrm{NO}_{3} \mathrm{R}_{\text {ext }}$.

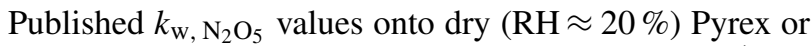
PFA tubing with 4 and $7 \mathrm{~cm}$ i.d. are 0.04 and $0.009 \mathrm{~s}^{-1}$, respectively (Wagner et al., 2008; Gržinić et al., 2015). Extrapolating these values to the LFR used here and then averaging them together yielded $k_{\mathrm{w}, \mathrm{N}_{2} \mathrm{O}_{5}}=0.05 \mathrm{~s}^{-1}$, which was applied in the LFR-KinSim model. In preliminary OFRKinSim modeling studies, we assumed $k_{\mathrm{w}, \mathrm{N}_{2} \mathrm{O}_{5}}=0.014 \mathrm{~s}^{-1}$ (Palm et al., 2017). However, as will be discussed in Sect. 3.3, $k_{\mathrm{W}, \mathrm{N}_{2} \mathrm{O}_{5}}$ was humidity-dependent and required modifications to match measured $\mathrm{NO}_{3}$ exp values as a function of $\mathrm{RH}_{\mathrm{OFR}}$.

\section{Results and discussion}

\subsection{LFR design considerations}

The optimal LFR residence time $\left(\tau_{\text {LFR }}\right)$ was identified using model simulations of the injection of $300 \mathrm{ppm} \mathrm{O}_{3}$ and $\mathrm{NO}_{2}$ into the LFR followed by dilution and injection of the LFR output into an OFR operated with $\tau_{\mathrm{OFR}}=120 \mathrm{~s}$. Fig- ure $\mathrm{S} 2$ plots the $\mathrm{NO}_{3} \exp$ achieved in the OFR as a function of $\tau_{\text {LFR }}$ ranging from 1 to $60 \mathrm{~s}$. Potential entry length effects that may have influenced results obtained below $\tau_{\mathrm{LFR}} \approx 4$ $5 \mathrm{~s}$ were not considered in the model. Figure $\mathrm{S} 2$ shows that the maximum $\mathrm{NO}_{3 \exp }$ in the OFR was obtained at $\tau_{\mathrm{LFR}}=$ $20 \mathrm{~s}$ at room temperature (unheated case); other $\mathrm{NO}_{3 \exp }$ values were normalized to this condition. Below $\tau_{\mathrm{LFR}}=20 \mathrm{~s}$, $\mathrm{NO}_{3 \exp }$ was suppressed due to higher $\mathrm{NO}_{2}$ levels entering the OFR. Above $\tau_{\mathrm{LFR}}=20 \mathrm{~s}, \mathrm{NO}_{3 \exp }$ was suppressed due to lower $\mathrm{N}_{2} \mathrm{O}_{5}$ levels entering the OFR because of more extensive LFR wall loss.

In traditional studies of $\mathrm{NO}_{3}$ oxidative aging processes that are conducted at low pressure and short residence time ( $\tau \sim 1 \mathrm{~s}), \mathrm{N}_{2} \mathrm{O}_{5}$ is heated to generate a burst of $\mathrm{NO}_{3}$ prior to injection into the system (Knopf et al., 2011). While not experimentally considered in this work, we modeled the $\mathrm{NO}_{3 \exp }$ achieved assuming complete thermal dissociation of $\mathrm{N}_{2} \mathrm{O}_{5}$ between the LFR and OFR - for example, by heating to $120^{\circ} \mathrm{C}$ for $300 \mathrm{~ms}$ (Wood et al., 2003). Figure S2 suggests that the effect of heating $\mathrm{N}_{2} \mathrm{O}_{5}$ on $\mathrm{NO}_{3}$ exp was most significant at short $\tau_{\text {LFR }}$, where $\left[\mathrm{N}_{2} \mathrm{O}_{5}\right]$ at the exit of the LFR was higher due to less wall loss and room-temperature decomposition. For example, at $\tau_{\mathrm{LFR}}=8 \mathrm{~s}$, the modeled $\mathrm{NO}_{3 \exp }$ was 2.8 times higher in the complete-dissociation case than in the unheated case, whereas $\mathrm{NO}_{3}$ exp increased by factors of 2.3 and 1.5 at $\tau_{\mathrm{LFR}}=20$ and $60 \mathrm{~s}$. Thus, a combination of reducing $\tau_{\text {LFR }}$ and heating $\mathrm{N}_{2} \mathrm{O}_{5}$ at the exit of the LFR increases $\mathrm{NO}_{3 \exp }$ and should be explored for future advanced implementations of OFR-iN $\mathrm{O}_{5}$.

\subsection{Example $\mathrm{OFR}-\mathrm{iN}_{2} \mathrm{O}_{5}$ characterization studies}

Figure 2a shows time series of $\mathrm{O}_{3}$ and $\mathrm{NO}_{2}$ concentrations during an OFR- $\mathrm{iN}_{2} \mathrm{O}_{5}$ characterization experiment where $\mathrm{RH}_{\mathrm{OFR}}=11 \%,\left[\mathrm{O}_{3}\right]_{0, \mathrm{LFR}}=280 \mathrm{ppm}$, and $\left[\mathrm{NO}_{2}\right]_{0, \mathrm{LFR}}=$ 0 to $320 \mathrm{ppm}$. Figure $2 \mathrm{~b}$ shows time series of acetonitrile $\left(\mathrm{C}_{2} \mathrm{H}_{3} \mathrm{~N}\right)$, butanal $\left(\mathrm{C}_{4} \mathrm{H}_{8} \mathrm{O}\right)$, thiophene $\left(\mathrm{C}_{4} \mathrm{H}_{4} \mathrm{~S}\right), 2$, 3dihydrobenzofuran $\left(\mathrm{C}_{8} \mathrm{H}_{8} \mathrm{O}\right)$, and naphthalene- $\mathrm{d}_{8}\left(\mathrm{C}_{10} \mathrm{D}_{8}\right)$ signals measured during the same period. Following $\mathrm{NO}_{3}$ generation, the fractional decay of $\mathrm{C}_{2} \mathrm{H}_{3} \mathrm{~N}, \mathrm{C}_{4} \mathrm{H}_{8} \mathrm{O}, \mathrm{C}_{4} \mathrm{H}_{4} \mathrm{~S}$, and $\mathrm{C}_{8} \mathrm{H}_{8} \mathrm{O}$ increased with increasing tracer $k_{\mathrm{NO}_{3}}$, as expected. $\mathrm{C}_{8} \mathrm{H}_{8} \mathrm{O}$ was too reactive to measure any significant changes in its decay as a function of OFR-i $\mathrm{N}_{2} \mathrm{O}_{5}$ conditions, as shown in Fig. 2; however, maximum decay of $\mathrm{C}_{4} \mathrm{H}_{8} \mathrm{O}$ and $\mathrm{C}_{4} \mathrm{H}_{4} \mathrm{~S}$ was observed at $\left[\mathrm{NO}_{2}\right]_{0, \mathrm{LFR}}:\left[\mathrm{O}_{3}\right]_{0, \mathrm{LFR}} \approx 0.7$ in this experiment. Decay of naphthalene- $\mathrm{d}_{8}$, which was influenced by both $\mathrm{NO}_{3}$ and $\mathrm{NO}_{2}$ concentrations (Table $\mathrm{S} 1$ ), was maximized at $\left[\mathrm{NO}_{2}\right]_{0, \mathrm{LFR}}:\left[\mathrm{O}_{3}\right]_{0, \mathrm{LFR}} \approx 0.3$ to 1.1 .

To confirm that the VOC degradation shown in Fig. $2 \mathrm{~b}$ was due to reaction with $\mathrm{NO}_{3}$, Fig. 3 shows IBBCEAS measurements of $\mathrm{NO}_{3}$ obtained in separate OFR-iN $\mathrm{O}_{5}$ characterization experiments that used $\left[\mathrm{O}_{3}\right]_{0, \mathrm{LFR}}=150-160 \mathrm{ppm}$ and $\left[\mathrm{NO}_{2}\right]_{0, \mathrm{LFR}}:\left[\mathrm{O}_{3}\right]_{0, \mathrm{LFR}}=0.75$ and 2.0. The maximum IBBCEAS signal observed at $\lambda=662 \mathrm{~nm}$ indicated the presence of $\mathrm{NO}_{3}$, as is evident from comparison with the 


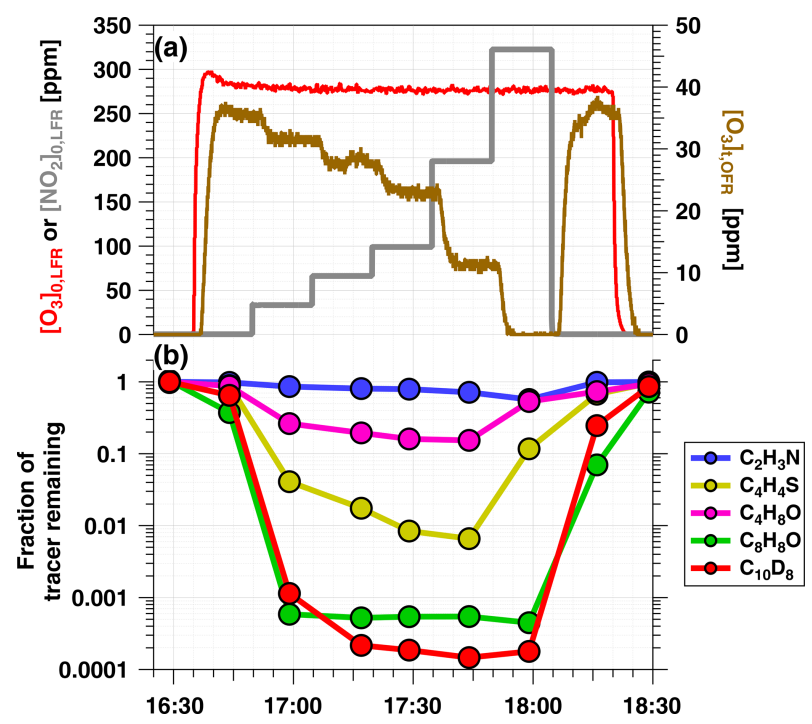

Figure 2. Time series from a representative $\mathrm{OFR}-\mathrm{iN}_{2} \mathrm{O}_{5}$ characterization experiment conducted at $\mathrm{RH}_{\mathrm{OFR}}=11 \%$ of (a) $\mathrm{O}_{3}$ and $\mathrm{NO}_{2}$ mixing ratios input to LFR (left axis) and $\mathrm{O}_{3}$ measured at the exit of the OFR (right axis), and (b) VOC tracers measured with PTRMS: acetonitrile $\left(\mathrm{C}_{2} \mathrm{H}_{3} \mathrm{~N}\right)$, butanal $\left(\mathrm{C}_{4} \mathrm{H}_{8} \mathrm{O}\right)$, thiophene $\left(\mathrm{C}_{4} \mathrm{H}_{4} \mathrm{~S}\right)$, 2, 3-dihydrobenzofuran $\left(\mathrm{C}_{8} \mathrm{H}_{8} \mathrm{O}\right)$, and naphthalene- $\mathrm{d}_{8}\left(\mathrm{C}_{10} \mathrm{D}_{8}\right)$.

wavelength-dependent absorption cross section of $\mathrm{NO}_{3} \mathrm{ob}-$ tained by Orphal et al. (2003) and plotted in Fig. 3b. Additionally, Fig. S3 shows the relative rate coefficient obtained from the decay of $\mathrm{C}_{4} \mathrm{H}_{8} \mathrm{O}$ and $\mathrm{C}_{4} \mathrm{H}_{4} \mathrm{~S}$ measured with PTR-MS. We measured a relative rate coefficient of 2.83 , which is in agreement with a relative rate coefficient value of $3.22 \pm 0.95$ calculated from $\mathrm{C}_{4} \mathrm{H}_{8} \mathrm{O}+\mathrm{NO}_{3}$ and $\mathrm{C}_{4} \mathrm{H}_{4} \mathrm{~S}+\mathrm{NO}_{3}$ rate coefficients (Atkinson, 1991; D' Anna et al., 2001). Ions corresponding to peroxy butyl nitrate, nitrothiophene, and nitronaphthalene- $\mathrm{d}_{7}$, which are known $\mathrm{NO}_{3}$ oxidation products of $\mathrm{C}_{4} \mathrm{H}_{8} \mathrm{O}, \mathrm{C}_{4} \mathrm{H}_{4} \mathrm{~S}$, and $\mathrm{C}_{10} \mathrm{D}_{8}$, respectively (Atkinson et al., 1990; Jenkin et al., 2003; Saunders et al., 2003; Cabañas et al., 2005), were also detected with PTR-MS. Tracer decay experiments similar to the measurements shown in Fig. 2 were repeated over $\left[\mathrm{O}_{3}\right]_{0, \mathrm{LFR}}$ ranging from 10 to $7400 \mathrm{ppm},\left[\mathrm{NO}_{2}\right]_{0}, \mathrm{LFR}$ ranging from 0 to $7200 \mathrm{ppm}$, and $\mathrm{RH}_{\mathrm{OFR}}$ ranging from $7 \%$ to $85 \%$. For experiments where $\left[\mathrm{O}_{3}\right]_{0, \mathrm{LFR}}>6000 \mathrm{ppm}, \mathrm{NO}_{3} \exp$ was calculated from the decay of $o$-xylene because (1) $p$-cymene has a large ionized fragment at $\mathrm{C}_{7} \mathrm{H}_{9}^{+}$(thus interfering with detection of toluene), (2) $\mathrm{NO}_{3}$ oxidation products were generated that interfered with detection of oxygenated tracers (butanol, benzaldehyde, and butanal), and (3) the remaining tracers that were used were too reactive towards $\mathrm{NO}_{3}$ to accurately constrain $\mathrm{NO}_{3 \exp }$.
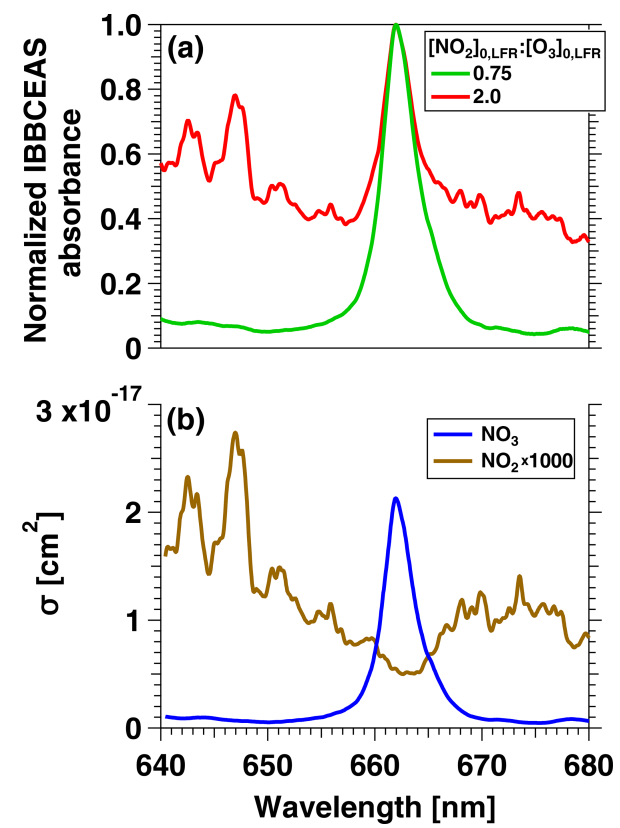

Figure 3. (a) IBBCEAS measurements of $\mathrm{NO}_{2}$ and $\mathrm{NO}_{3}$ absorbance obtained from an OFR-i $\mathrm{N}_{2} \mathrm{O}_{5}$ characterization experiment conducted at $\left[\mathrm{O}_{3}\right]_{0, \mathrm{LFR}}=150-160 \mathrm{ppm}$ and $\left[\mathrm{NO}_{2}\right]_{0, \mathrm{LFR}}$ : $\left[\mathrm{O}_{3}\right]_{0, \mathrm{LFR}}=0.75$ and 2.0. (b) Absorption cross sections of $\mathrm{NO}_{2}$ and $\mathrm{NO}_{3}$ (Vandaele et al., 1998; Orphal et al., 2003).

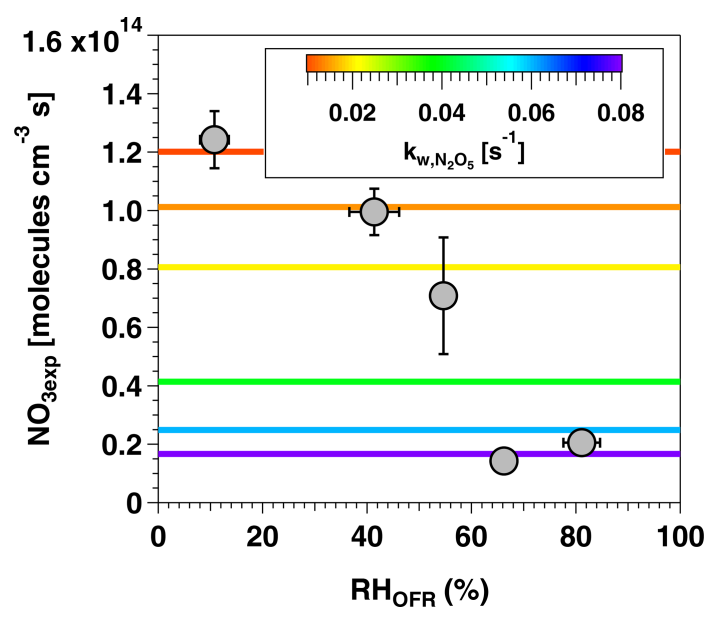

Figure 4. $\mathrm{NO}_{3}$ exp as a function of $\mathrm{RH}_{\mathrm{OFR}}$ at $\left[\mathrm{O}_{3}\right]_{0, \mathrm{LFR}}=250 \mathrm{ppm}$ and $\left[\mathrm{NO}_{2}\right]_{0, \mathrm{LFR}}=130 \mathrm{ppm}$. Horizontal lines represent $\mathrm{N}_{2} \mathrm{O}_{5}$ wall loss rate constants ranging from 0.01 to $0.08 \mathrm{~s}^{-1}$ that were input to the OFR-iN $\mathrm{O}_{5}$ KinSim mechanism (Table S2).

\subsection{Effect of $\mathrm{RH}_{\mathrm{OFR}},\left[\mathrm{O}_{3}\right]_{0, \mathrm{LFR}}$, and $\left[\mathrm{NO}_{2}\right]_{0, \mathrm{LFR}}$ on $\mathrm{NO}_{3 \exp }$}

Figure 4 shows $\mathrm{NO}_{3} \exp$ as a function of $\mathrm{RH}_{\mathrm{OFR}}$ at $\left[\mathrm{O}_{3}\right]_{0, \mathrm{LFR}}=250 \mathrm{ppm}$ and $\left[\mathrm{NO}_{2}\right]_{0, \mathrm{LFR}}=130 \mathrm{ppm}$. Under these conditions, $\mathrm{NO}_{3 \exp }$ decreased from $1.2 \times 10^{14}$ to $2.0 \times$ $10^{13}$ molecules $\mathrm{cm}^{-3} \mathrm{~s}$ as $\mathrm{RH}_{\mathrm{OFR}}$ increased from $11 \%$ to $81 \%$. We hypothesize that this result is due to more effi- 
cient hydrolysis of $\mathrm{N}_{2} \mathrm{O}_{5}$ to $\mathrm{HNO}_{3}$ on the wetted walls of the OFR at higher $\mathrm{RH}$, thereby suppressing $\mathrm{NO}_{3 \exp }$ relative to values obtained at lower RH conditions. In an attempt to model this behavior, $k_{\mathrm{W}, \mathrm{N}_{2} \mathrm{O}_{5}}$ values input to the model were adjusted as a function of $\mathrm{RH}_{\mathrm{OFR}}$. Figure 4 suggests

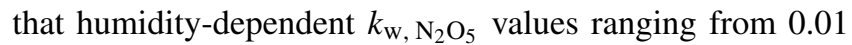
to $0.08 \mathrm{~s}^{-1}$ were required to cover the range of measured $\mathrm{NO}_{3}$ exp . These values agreed within a factor of 2 or better

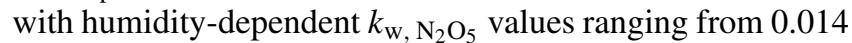
to $0.040 \mathrm{~s}^{-1}$ measured by Palm et al. (2017) in a similar OFR and were applied in subsequent model calculations.

Figure 5 shows $\mathrm{NO}_{3}$ exp as a function of $\left[\mathrm{O}_{3}\right]_{0, \mathrm{LFR}}$ for measurements with $\left[\mathrm{NO}_{2}\right]_{0, \mathrm{LFR}}:\left[\mathrm{O}_{3}\right]_{0, \mathrm{LFR}}=0.5 \pm 0.1$ and $\mathrm{RH}_{\mathrm{OFR}}=11 \pm 2 \%$. The equivalent ambient photochemical age shown on the right $y$ axis was calculated assuming a $14 \mathrm{~h}$ average nighttime $\mathrm{NO}_{3}$ mixing ratio of $30 \mathrm{ppt}$ and a $10 \mathrm{~h}$ daytime $\mathrm{NO}_{3}$ mixing ratio of $0 \mathrm{ppt}$ (Asaf et al., 2010). $\mathrm{NO}_{3 \text { exp }}$ increased with increasing $\left[\mathrm{O}_{3}\right]_{0, \mathrm{LFR}}$ due to increased $\mathrm{NO}_{3}$ production from higher $\left[\mathrm{N}_{2} \mathrm{O}_{5}\right]$. Over the range of measured conditions, increasing $\left[\mathrm{O}_{3}\right]_{0, \mathrm{LFR}}$ from 33 to $7092 \mathrm{ppm}$ increased $\mathrm{NO}_{3 \exp }$ from $6.4 \times 10^{12}$ to $4.0 \times$ $10^{15}$ molecules $\mathrm{cm}^{-3} \mathrm{~s}^{-1}$. The black line in Fig. 5 represents $\mathrm{NO}_{3}$ exp modeled using the mechanism shown in Table S2. Measured and modeled $\mathrm{NO}_{3 \exp }$ values agreed within a factor of 2 or better above $\left[\mathrm{O}_{3}\right]_{0, \mathrm{LFR}} \approx 40 \mathrm{ppm}$, and the gain in $\mathrm{NO}_{3}$ exp as a function of $\left[\mathrm{O}_{3}\right]_{0, \mathrm{LFR}}$ was highest between $\left[\mathrm{O}_{3}\right]_{0, \text { LFR }} \approx 10$ and $300 \mathrm{ppm}$. Over this range of $\left[\mathrm{O}_{3}\right]_{0, \text { LFR }}$, the $\mathrm{NO}_{2}$ oxidation lifetime with respect to $\mathrm{O}_{3}$ decreased from 115 to $4 \mathrm{~s}$. Because $\tau_{\mathrm{LFR}}=20 \mathrm{~s}$, under this range of LFR conditions, the $\mathrm{NO}_{2}$ lifetime in the LFR was long enough that high $\mathrm{NO}_{2}$ levels exiting the LFR suppressed $\mathrm{NO}_{3} \exp$ in the OFR. In contrast, increasing $\left[\mathrm{O}_{3}\right]_{0, \mathrm{LFR}}$ from 300 to $7000 \mathrm{ppm}$ decreased the $\mathrm{NO}_{2}$ oxidation lifetime with respect to $\mathrm{O}_{3}$ from 4 to $0.2 \mathrm{~s}$, and $\left[\mathrm{NO}_{2}\right]$ exiting the LFR was too low to significantly affect $\mathrm{NO}_{3 \exp }$. To support this hypothesis, Fig. 6 plots $\mathrm{NO}_{3}$ exp as a function of $\left[\mathrm{NO}_{2}\right]_{0, \mathrm{LFR}}:\left[\mathrm{O}_{3}\right]_{0, \mathrm{LFR}}$ at $\left[\mathrm{O}_{3}\right]_{0, \mathrm{LFR}}=250 \pm 20 \mathrm{ppm}$ and $6850 \pm 400 \mathrm{ppm}$. Here, we incorporated $\mathrm{NO}_{3 \exp }$ values obtained over $\mathrm{RH}_{\text {OFR }}=11 \%$ to $81 \%$ for better statistics, and normalized each $\mathrm{NO}_{3 \exp }$ value to the maximum $\mathrm{NO}_{3} \exp$ obtained at the same $\mathrm{RH}$. Figure 6 shows that at $\left[\mathrm{O}_{3}\right]_{0, \mathrm{LFR}}=250 \mathrm{ppm}$, the maximum $\mathrm{NO}_{3, \text { exp }}$ was achieved at $\left[\mathrm{NO}_{2}\right]_{0, \mathrm{LFR}}:\left[\mathrm{O}_{3}\right]_{0, \mathrm{LFR}} \approx 0.5$ to 0.7 . Conversely, at $\left[\mathrm{O}_{3}\right]_{0, \mathrm{LFR}}=6850 \mathrm{ppm}$, the maximum $\mathrm{NO}_{3}$ exp value was achieved at $\left[\mathrm{NO}_{2}\right]_{0, \mathrm{LFR}}:\left[\mathrm{O}_{3}\right]_{0, \mathrm{LFR}} \approx 1.2$.

In a related set of experiments, IBBCEAS measurements of the $\mathrm{NO}_{2}: \mathrm{NO}_{3}$ ratio at the exit of the OFR (obtained from Fig. 3a spectra) confirmed that significantly higher $\mathrm{NO}_{2}$ levels were present in the OFR at higher $\left[\mathrm{NO}_{2}\right]_{0, \mathrm{LFR}}:\left[\mathrm{O}_{3}\right]_{0, \mathrm{LFR}}$, as expected. For example, at $\left[\mathrm{O}_{3}\right]_{0, \mathrm{LFR}}=150 \mathrm{ppm}$ and $\left[\mathrm{NO}_{2}\right]_{0, \mathrm{LFR}}=112 \mathrm{ppm}$, $\mathrm{NO}_{2}: \mathrm{NO}_{3}=28$, whereas at $\left[\mathrm{O}_{3}\right]_{0, \mathrm{LFR}}=160 \mathrm{ppm}$ and $\left[\mathrm{NO}_{2}\right]_{0, \mathrm{LFR}}=320 \mathrm{ppm}, \quad \mathrm{NO}_{2}: \mathrm{NO}_{3}=613 . \quad \mathrm{NO}_{2}: \mathrm{NO}_{3}$, along with $\mathrm{NO}_{3}: \mathrm{O}_{3}$ and $\mathrm{NO}_{2}: \mathrm{NO}_{3}$, has important implications for the fate of organic species in OFR-i $\mathrm{N}_{2} \mathrm{O}_{5}$ that are discussed in the following sections.

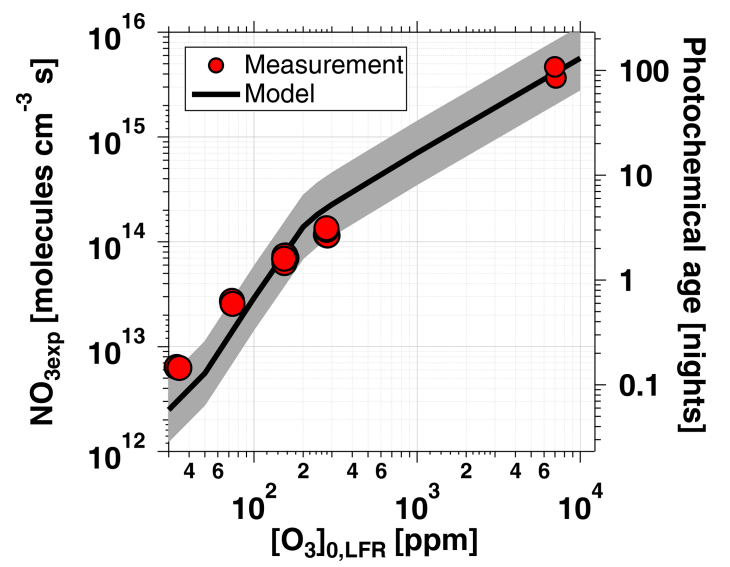

Figure 5. $\mathrm{NO}_{3} \exp$ as a function of $\left[\mathrm{O}_{3}\right]_{0, \mathrm{LFR}}$ for measurements with $\left[\mathrm{NO}_{2}\right]_{0, \mathrm{LFR}}:\left[\mathrm{O}_{3}\right]_{0, \mathrm{LFR}}=0.5 \pm 0.1$. Equivalent ambient photochemical age was calculated assuming a $14 \mathrm{~h}$ average nighttime $\mathrm{NO}_{3}$ mixing ratio of $30 \mathrm{ppt}$ and $10 \mathrm{~h}$ daytime average $\mathrm{NO}_{3}$ mixing ratio of 0 ppt (Asaf et al., 2010). Model inputs were $k_{\mathrm{w}, \mathrm{N}_{2} \mathrm{O}_{5}}=0.01 \mathrm{~s}^{-1}$ and $\mathrm{NO}_{3} \mathrm{R}_{\mathrm{ext}}=0.07 \mathrm{~s}^{-1}\left(\left[\mathrm{O}_{3}\right]_{0, \mathrm{LFR}}<\right.$ $1000 \mathrm{ppm})$ or $0.38 \mathrm{~s}^{-1}\left(\left[\mathrm{O}_{3}\right]_{0, \mathrm{LFR}}>1000 \mathrm{ppm}\right)$. The shaded region encompasses model output scaled by factors of 0.5 and 2 .

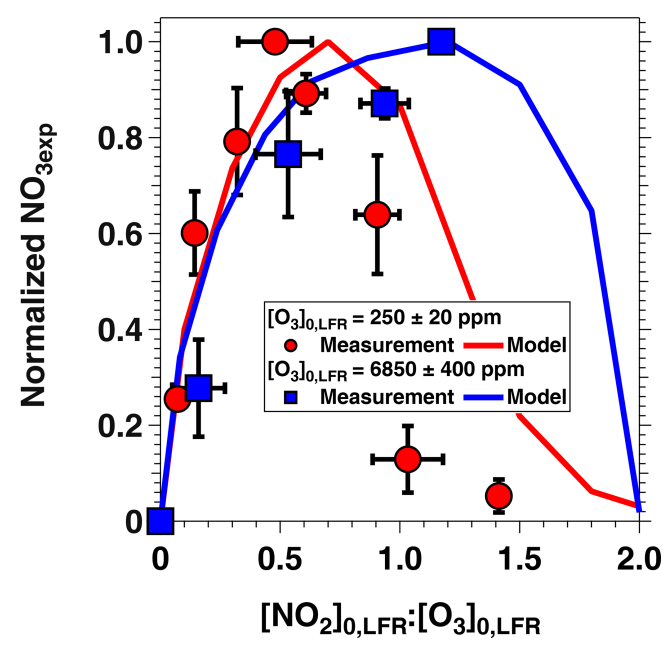

Figure 6. $\mathrm{NO}_{3} \exp$ as a function of $\left[\mathrm{NO}_{2}\right] 0, \mathrm{LFR}:\left[\mathrm{O}_{3}\right]_{0, \mathrm{LFR}}$ at fixed $\left[\mathrm{O}_{3}\right]_{0, \mathrm{LFR}}$ values of $250 \pm 20$ and $6850 \pm 400 \mathrm{ppm}$ and $\mathrm{RH}_{\mathrm{OFR}}=11 \%$ to $81 \% . \mathrm{NO}_{3} \exp$ values were normalized to the maximum $\mathrm{NO}_{3}$ exp value obtained at the same $\mathrm{RH}$.

\subsection{Model characterization of $\mathrm{OFR}-\mathrm{iN}_{2} \mathrm{O}_{5}: \mathrm{NO}_{3}: \mathrm{O}_{3}$, $\mathrm{NO}_{2}: \mathrm{NO}_{3}$, and $\mathrm{NO}_{2}: \mathrm{O}_{2}$}

To examine OFR-i $\mathrm{N}_{2} \mathrm{O}_{5}$ performance over a wider range of conditions, Fig. 7 plots the mean $\mathrm{NO}_{3} \exp ,\left[\mathrm{O}_{3}\right], \mathrm{NO}_{3}: \mathrm{O}_{3}$, $\mathrm{NO}_{2}: \mathrm{NO}_{3}$, and $\mathrm{NO}_{2}: \mathrm{O}_{2}$ values obtained with the model as a function of $\left[\mathrm{O}_{3}\right]_{0, \mathrm{LFR}}=10$ to $10^{5} \mathrm{ppm}(10 \%)$, for $\left[\mathrm{NO}_{2}\right]_{0, \mathrm{LFR}}:\left[\mathrm{O}_{3}\right]_{0, \mathrm{LFR}}=0.01,0.1,0.5,1.0,1.5,1.8$, and 2.0. Three observations are apparent from Fig. 7. First, at $\left[\mathrm{O}_{3}\right]_{0, \mathrm{LFR}}<1000 \mathrm{ppm}$ and $\left[\mathrm{NO}_{2}\right]_{0, \mathrm{LFR}}:\left[\mathrm{O}_{3}\right]_{0, \mathrm{LFR}}=0.01$ 


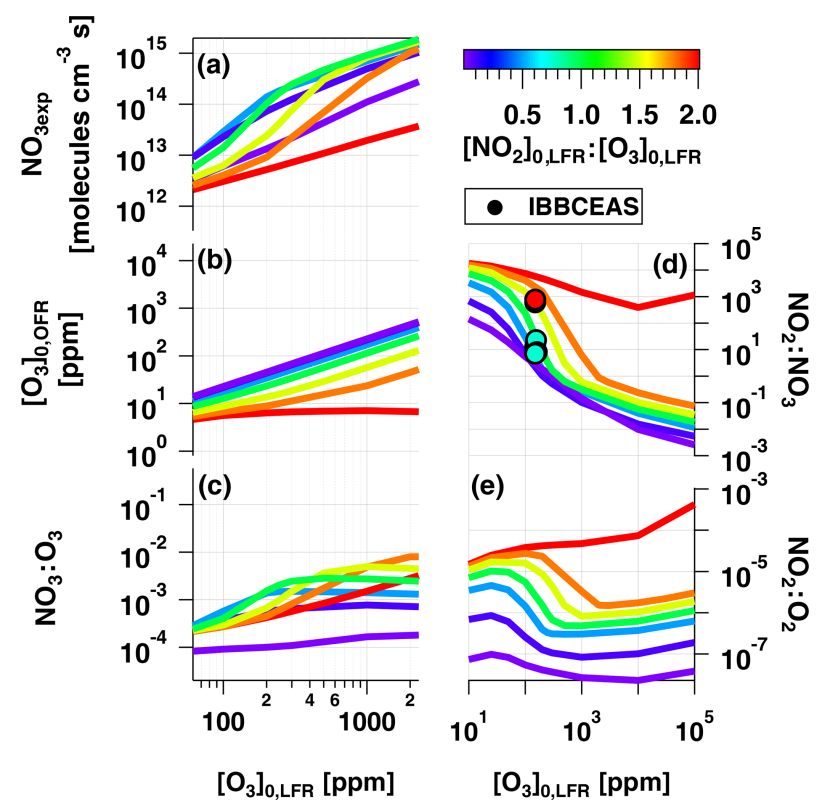

Figure 7. Modeled (a) $\mathrm{NO}_{3} \exp$, (b) $\left[\mathrm{O}_{3}\right]$, (c) $\mathrm{NO}_{3}: \mathrm{O}_{3}$, (d) $\mathrm{NO}_{2}: \mathrm{NO}_{3}$, and (e) $\mathrm{NO}_{2}: \mathrm{O}_{2}$ as a function of $\left[\mathrm{O}_{3}\right]_{0, \mathrm{LFR}}=10$ to $10^{5} \mathrm{ppm}$, for $\left[\mathrm{NO}_{2}\right]_{0, \mathrm{LFR}}:\left[\mathrm{O}_{3}\right]_{0, \mathrm{LFR}}=0.01,0.1,0.5,1.0,1.5$, 1.8, and 2.0. Model inputs were $k_{\mathrm{w}, \mathrm{N}_{2} \mathrm{O}_{5}}=0.01 \mathrm{~s}^{-1}, \mathrm{NO}_{3} \mathrm{R}_{\text {ext }}=$ $0.07 \mathrm{~s}^{-1}$. IBBCEAS-measured $\mathrm{NO}_{2}: \mathrm{NO}_{3}$ values are plotted in (d).

to 1.8 , the maximum $\mathrm{NO}_{3 \exp }$ increased with $\left[\mathrm{NO}_{2}\right]_{0, \mathrm{LFR}}$ : $\left[\mathrm{O}_{3}\right]_{0, \mathrm{LFR}}$ prior to decreasing at $\left[\mathrm{NO}_{2}\right]_{0, \mathrm{LFR}}:\left[\mathrm{O}_{3}\right]_{0, \mathrm{LFR}}>$ 1.0 (Fig. 7a). Above $\left[\mathrm{O}_{3}\right]_{0, \mathrm{LFR}} \approx 2000 \mathrm{ppm}$ and below $\left[\mathrm{NO}_{2}\right]_{0, \mathrm{LFR}}:\left[\mathrm{O}_{3}\right]_{0, \mathrm{LFR}}=2.0, \mathrm{NO}_{3} \exp$ was less sensitive to $\left[\mathrm{NO}_{2}\right]_{0, \mathrm{LFR}}:\left[\mathrm{O}_{3}\right]_{0, \mathrm{LFR}}$. Second, the maximum $\mathrm{NO}_{3}$ : $\mathrm{O}_{3}$ increased with increasing $\left[\mathrm{NO}_{2}\right]_{0, \mathrm{LFR}}:\left[\mathrm{O}_{3}\right]_{0, \text { LFR }}$ above $\left[\mathrm{O}_{3}\right]_{0, \mathrm{LFR}}=1000 \mathrm{ppm}$ (Fig. $7 \mathrm{c}$ ). Third, the $\left[\mathrm{NO}_{2}\right]_{0, \mathrm{LFR}}$ : $\left[\mathrm{O}_{3}\right]_{0, \mathrm{LFR}}=2.0$ case demonstrated unique behavior relative to the other cases because residual $\mathrm{O}_{3}$ exiting the LFR was low $(<10 \mathrm{ppm})$ due to almost complete conversion of $\mathrm{O}_{3}$ to $\mathrm{O}_{2}$ inside the LFR (Fig. 7b). Consequently, the high residual $\left[\mathrm{NO}_{2}\right]$ suppressed $\mathrm{NO}_{3}$ exp by 1 to 2 orders of magnitude relative to $\left[\mathrm{NO}_{2}\right]_{0, \text { LFR }}:\left[\mathrm{O}_{3}\right]_{0, \text { LFR }}<2$ cases (Fig. 7a) and generated enhanced $\mathrm{NO}_{3}: \mathrm{O}_{3}, \mathrm{NO}_{2}: \mathrm{NO}_{3}$, and $\mathrm{NO}_{2}: \mathrm{O}_{2}$ values. In addition, $\mathrm{NO}_{2}: \mathrm{NO}_{3}$ ratios obtained from IBBCEAS measurements at $\left[\mathrm{O}_{3}\right]_{0, \mathrm{LFR}}=150$ to $160 \mathrm{ppm}$ and $\left[\mathrm{NO}_{2}\right]_{0, \mathrm{LFR}}$ : $\left[\mathrm{O}_{3}\right]_{0, \mathrm{LFR}}=0.75,1.0$ and 2.0 are shown in Fig. $7 \mathrm{~d}$. The measured $\mathrm{NO}_{2}: \mathrm{NO}_{3}$ values are comparable to, or lower than, the modeled $\mathrm{NO}_{2}: \mathrm{NO}_{3}$ values obtained under similar conditions and, therefore, broadly support using model results to further investigate the fate of (1) $\mathrm{RO}_{2}$ formed from $\mathrm{NO}_{3}$ oxidation of VOCs, (2) alkyl radicals that are reactive towards $\mathrm{NO}_{2}$ and $\mathrm{O}_{2}$, and (3) VOCs that are reactive towards $\mathrm{O}_{3}$ and $\mathrm{NO}_{3}$ in the following sections.

\subsubsection{Fate of organic peroxy radicals $\left(\mathrm{RO}_{2}\right)$ formed from $\mathrm{NO}_{3}+$ VOC reactions}

Organic peroxy radicals $\left(\mathrm{RO}_{2}\right)$ react with $\mathrm{NO}, \mathrm{NO}_{2}, \mathrm{NO}_{3}$, $\mathrm{HO}_{2}$, or other $\mathrm{RO}_{2}$ to generate alkoxy (RO) radicals, peroxynitrates $\left(\mathrm{RO}_{2} \mathrm{NO}_{2}\right)$, hydroperoxides or organic peroxides, and may additionally undergo autooxidation via sequential isomerization and $\mathrm{O}_{2}$ addition. To investigate the fate of $\mathrm{RO}_{2}$ as a function of OFR-iN $\mathrm{O}_{5}$ conditions, we applied the methodology of Peng et al. (2019) by calculating the fractional oxidative loss of a generic alkyl or acyl $\mathrm{RO}_{2}$ to each of these species over the range of conditions shown in Fig. 7. Kinetic data from Orlando and Tyndall (2012) that were used in these calculations are summarized in Table S4. Under almost all OFR-i $\mathrm{N}_{2} \mathrm{O}_{5}$ conditions shown in Fig. 7, $\mathrm{RO}_{2}$ reactions with $\mathrm{NO}, \mathrm{HO}_{2}$, and $\mathrm{RO}_{2}$ were minor $(<1 \%)$ loss pathways compared with reaction with $\mathrm{NO}_{2}$ and $\mathrm{NO}_{3}$. We conducted a model sensitivity analysis in which the $\mathrm{RO}_{2}+\mathrm{RO}_{2}$ reaction rate was enhanced by increasing $\mathrm{NO}_{3} R_{\text {ext }}$ from 0.07 to $0.7 \mathrm{~s}^{-1}$ and increasing the $\mathrm{RO}_{2}+\mathrm{RO}_{2}$ rate constant from $1 \times 10^{-11}$ to $1 \times 10^{-10} \mathrm{~cm}^{3}$ molecule ${ }^{-1} \mathrm{~s}^{-1}$ (Berndt et al., $2018 \mathrm{a}, \mathrm{b})$. Despite these perturbations, the relative contribution of $\mathrm{RO}_{2}+\mathrm{RO}_{2}$ reactions to total $\mathrm{RO}_{2}$ loss remained $<1 \%$ across this range of $\mathrm{OFR}-\mathrm{iN}_{2} \mathrm{O}_{5}$ conditions.

To investigate the relative importance of competing $\mathrm{RO}_{2}+$ $\mathrm{NO}_{2}$ and $\mathrm{RO}_{2}+\mathrm{NO}_{3}$ pathways, we defined the fractional reactive loss of $\mathrm{RO}_{2}$ due to $\mathrm{NO}_{3}, F_{\mathrm{RO}_{2}+\mathrm{NO}_{3}}$ :

$$
F_{\mathrm{RO}_{2}+\mathrm{NO}_{3}}=\frac{k_{\mathrm{RO}_{2}+\mathrm{NO}_{3}}\left[\mathrm{NO}_{3}\right]}{k_{\mathrm{RO}_{2}+\mathrm{NO}_{3}}\left[\mathrm{NO}_{3}\right]+k_{\mathrm{RO}_{2}+\mathrm{NO}_{2}}\left[\mathrm{NO}_{2}\right]}
$$

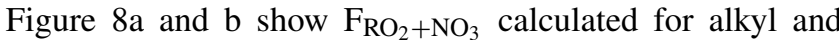
acyl $\mathrm{RO}_{2}$, respectively. To simplify the analysis, we assumed that the thermal decomposition of $\mathrm{RO}_{2} \mathrm{NO}_{2}$ species formed from $\mathrm{RO}_{2}+\mathrm{NO}_{2}$ reactions was slow compared with $\tau_{\mathrm{OFR}}$. This assumption generates a lower limit $\mathrm{F}_{\mathrm{RO}_{2}+\mathrm{NO}_{3}}$ value for the alkyl $\mathrm{RO}_{2}$ case, where $\mathrm{RO}_{2} \mathrm{NO}_{2}$ decomposition occurs on timescales of seconds or less (Orlando and Tyndall, 2012) but has minimal influence on the acyl- $\mathrm{RO}_{2}$ case due to higher thermal stability of peroxyl acyl nitrates. For alkyl $\mathrm{RO}_{2}$, Fig. 8a shows that $F_{\mathrm{RO}_{2}+\mathrm{NO}_{3}}=0.5$ was achieved between $\left[\mathrm{NO}_{2}, \mathrm{O}_{3}\right]_{0, \mathrm{LFR}}=(125 \mathrm{ppm}, 250 \mathrm{ppm})$ and $(3240 \mathrm{ppm}, 1800 \mathrm{ppm})$. For acyl $\mathrm{RO}_{2}$, due to faster re-

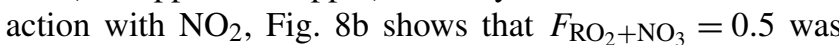
achieved using $\left[\mathrm{NO}_{2}, \mathrm{O}_{3}\right]_{0, \mathrm{LFR}}=(350 \mathrm{ppm}, 700 \mathrm{ppm})$ to $(1.1 \%, 0.6 \%)$.

To investigate the feasibility of generating OFR-i $\mathrm{N}_{2} \mathrm{O}_{5}$ conditions where $\mathrm{RO}_{2}$ loss is dominated by autooxidation, we calculated the lifetime of alkyl and acyl $\mathrm{RO}_{2}\left(\tau_{\mathrm{RO}_{2}}\right)$ over the range of OFR-iN $\mathrm{N}_{2} \mathrm{O}_{5}$ conditions shown in Fig. 7 and Fig. 8a and b. As shown in Fig. 8d and e, maximum $\tau_{\mathrm{RO}_{2}}$ values of $\approx 1.4 \mathrm{~s}$ (alkyl) and $0.4 \mathrm{~s}$ (acyl) were obtained at $\left[\mathrm{NO}_{2}\right]_{0, \mathrm{LFR}} \approx 2 \mathrm{ppm}$ and $\left[\mathrm{O}_{3}\right]_{0, \mathrm{LFR}} \approx 200 \mathrm{ppm}$. At lower $\left[\mathrm{O}_{3}\right]_{0, \mathrm{LFR}}, \tau_{\mathrm{RO}_{2}}$ decreased due to a faster $\mathrm{RO}_{2}+\mathrm{NO}_{2}$ reaction rate, and at higher $\left[\mathrm{O}_{3}\right]_{0, \mathrm{LFR}}, \tau_{\mathrm{RO}_{2}}$ decreased due to a faster $\mathrm{RO}_{2}+\mathrm{NO}_{3}$ reaction rate. Because $\mathrm{RO}_{2}$ autooxidation 


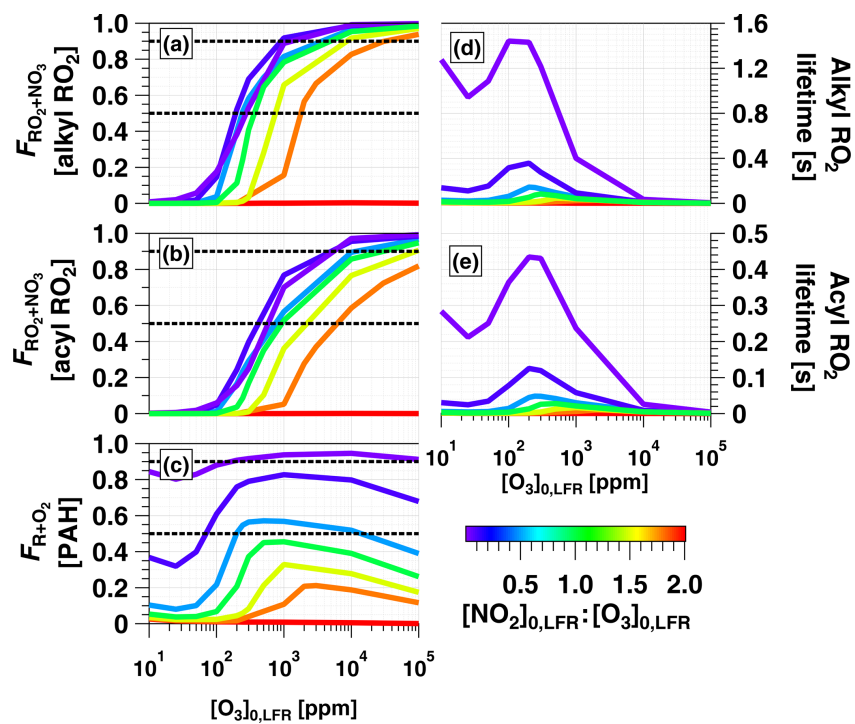

Figure 8. $F_{\mathrm{RO}_{2}+\mathrm{NO}_{3}}$ for (a) alkyl and (b) acyl $\mathrm{RO}_{2}$, and (c) $F_{\mathrm{R}+\mathrm{O}_{2}}$ over the same OFR-i $\mathrm{N}_{2} \mathrm{O}_{5}$ operating conditions and model inputs used to generate Fig. 7, with the corresponding lifetimes for (d) alkyl and (e) acyl $\mathrm{RO}_{2}$.

timescales range from 0.005 to $200 \mathrm{~s}$ depending on the specific $\mathrm{RO}_{2}$ composition (Crounse et al., 2013), OFR-i $\mathrm{N}_{2} \mathrm{O}_{5}$ may achieve autooxidation-dominant conditions for some $\mathrm{RO}_{2}$ but not for others.

\subsubsection{Fate of aromatic alkyl radicals $(R)$ formed from $\mathrm{NO}_{3}+$ VOC reactions}

The majority of aromatic alkyl radicals $(\mathrm{R})$ that are generated from $\mathrm{NO}_{3}$ oxidation of VOCs quickly react with $\mathrm{O}_{2}$ to generate $\mathrm{RO}_{2}$. However, $\mathrm{NO}_{3}$ oxidation of a subset of aromatic VOCs generates $\mathrm{R}$ that react more slowly with $\mathrm{O}_{2}$, thereby enabling competing reactions with $\mathrm{NO}_{2}$. For example, the phenoxy radical $\left(\mathrm{C}_{6} \mathrm{H}_{5} \mathrm{O}\right)$ generated from $\mathrm{NO}_{3}$ oxidation of phenol $\left(\mathrm{C}_{6} \mathrm{H}_{5} \mathrm{OH}\right)$ has $k_{\mathrm{O}_{2}}: k_{\mathrm{NO}_{2}}<2.4 \times 10^{-9}$ (Platz et al., 1998), and the $\mathrm{C}_{10} \mathrm{H}_{7} \mathrm{NO}_{3}$ radical that is generated from $\mathrm{NO}_{3}$ oxidation of naphthalene $\left(\mathrm{C}_{10} \mathrm{H}_{8}\right)$ has $k_{\mathrm{O}_{2}}: k_{\mathrm{NO}_{2}}<4 \times 10^{-7}$ (Atkinson et al., 1994). Alkyl radicals generated from $\mathrm{NO}_{3}$ oxidation of other PAHs may behave similarly to $\mathrm{C}_{10} \mathrm{H}_{7} \mathrm{NO}_{3}$, but kinetic data are unavailable in the literature. To investigate the relative importance of competing $\mathrm{R}+\mathrm{NO}_{2}$ and $\mathrm{R}+\mathrm{O}_{2}$ reactions in these systems, we defined the fractional reactive loss of $\mathrm{R}$ with respect to $\mathrm{O}_{2}, F_{\mathrm{R}+\mathrm{O}_{2}}$ :

$F_{\mathrm{R}+\mathrm{O}_{2}}=\frac{k_{\mathrm{R}+\mathrm{O}_{2}}\left[\mathrm{O}_{2}\right]}{k_{\mathrm{R}+\mathrm{O}_{2}}\left[\mathrm{O}_{2}\right]+k_{\mathrm{R}+\mathrm{NO}_{2}}\left[\mathrm{NO}_{2}\right]}$

Figure $8 \mathrm{c}$ shows $F_{\mathrm{R}+\mathrm{O}_{2}}$ over the same OFR-iN $\mathrm{O}_{2} \mathrm{O}_{5}$ operating conditions used to generate Fig. 7 and Fig. 8a and b. For $\mathrm{C}_{6} \mathrm{H}_{5} \mathrm{O}$ (not shown), $F_{\mathrm{R}+\mathrm{O}_{2}}<0.08$ over the entire range of OFR-iN $\mathrm{N}_{2} \mathrm{O}_{5}$ conditions shown in Figs. 7e and 8c. For $\mathrm{C}_{10} \mathrm{H}_{7} \mathrm{NO}_{3}, F_{\mathrm{R}+\mathrm{O}_{2}} \geq 0.5$ was achieved for the majority of OFR-iN $\mathrm{O}_{5}$ conditions where $\left[\mathrm{NO}_{2}\right]_{0, \mathrm{LFR}}:\left[\mathrm{O}_{3}\right]_{0, \mathrm{LFR}} \leq$ 0.1 and also between $\left[\mathrm{NO}_{2}, \mathrm{O}_{3}\right]_{0, \mathrm{LFR}}=(100 \mathrm{ppm}, 200 \mathrm{ppm})$ and $(5000 \mathrm{ppm}, 10000 \mathrm{ppm})$. The use of $\left[\mathrm{NO}_{2}\right]_{0, \mathrm{LFR}}$ : $\left[\mathrm{O}_{3}\right]_{0, \mathrm{LFR}} \geq 1$ always generated conditions where the reaction rate of $\mathrm{R}+\mathrm{NO}_{2}$ exceeded $\mathrm{R}+\mathrm{O}_{2}$.

\subsubsection{Fate of VOCs reactive towards $\mathrm{O}_{3}$ and $\mathrm{NO}_{3}$}

We defined the fractional reactive loss of a VOC with respect to $\mathrm{NO}_{3}, F_{\mathrm{VOC}+\mathrm{NO}_{3}}$ :

$F_{\mathrm{VOC}+\mathrm{NO}_{3}}=\frac{k_{\mathrm{VOC}+\mathrm{NO}_{3}}\left[\mathrm{NO}_{3}\right]}{k_{\mathrm{VOC}+\mathrm{NO}_{3}}\left[\mathrm{NO}_{3}\right]+k_{\mathrm{VOC}+\mathrm{O}_{3}}\left[\mathrm{O}_{3}\right]}$

and we established $\mathrm{F}_{\mathrm{VOC}+\mathrm{NO}_{3}}=0.9$ as the criterion for $\mathrm{NO}_{3}$-dominated oxidative loss. Figure 9 plots $\mathrm{NO}_{3}: \mathrm{O}_{3}$ at which $F_{\mathrm{VOC}+\mathrm{NO}_{3}}=0.9$ for several classes of organic compounds with published $k_{\mathrm{NO}_{3}}$ and $k_{\mathrm{O}_{3}}$ values greater than $10^{-16}$ and $10^{-19} \mathrm{~cm}^{-3}$ molecules ${ }^{-1} \mathrm{~s}^{-1}$, respectively. Therefore, this figure excludes compounds such as alkanes and monocyclic aromatics that react slowly with $\mathrm{NO}_{3}$ and are essentially unreactive towards $\mathrm{O}_{3}\left(F_{\mathrm{NO}_{3}} \approx 1\right) . \mathrm{NO}_{3}: \mathrm{O}_{3}$ values that correspond to $\left[\mathrm{NO}_{2}\right]_{0, \mathrm{LFR}}$ and $\left[\mathrm{O}_{3}\right]_{0, \mathrm{LFR}}=(2 \mathrm{ppm}$, $200 \mathrm{ppm}),(150 \mathrm{ppm}, 300 \mathrm{ppm})$, and (5400 ppm, $3000 \mathrm{ppm})$ are represented by horizontal bands with upper and lower limit values calculated assuming $k_{\mathrm{w}, \mathrm{N}_{2} \mathrm{O}_{5}}$ values of 0.01 and $0.08 \mathrm{~s}^{-1}$ (Sect. 3.3). These LFR inputs generated OFR$\mathrm{iN}_{2} \mathrm{O}_{5}$ conditions that maximize the $\mathrm{RO}_{2}$ lifetime and $\mathrm{NO}_{3}$ : $\mathrm{O}_{3}$ at $\left[\mathrm{NO}_{2}\right]:\left[\mathrm{O}_{3}\right]_{0, \mathrm{LFR}}=0.5$ and 1.8 , respectively (Figs. 7 , 8 ). Figures 7 and 9 as well as kinetic data from the literature suggest that the injection of $2 \mathrm{ppm} \mathrm{NO}_{2}$ and $200 \mathrm{ppm}$ $\mathrm{O}_{3}$ into the LFR was sufficient to achieve $F_{\mathrm{VOC}+\mathrm{NO}_{3}} \geq 0.9$ for phenols, PAHs with no double bonds, and mono- and sesquiterpenes with one double bond at low $\mathrm{RH}_{\mathrm{OFR}}$. Increasing $\left[\mathrm{NO}_{2}\right]_{0, \mathrm{LFR}}$ to $150 \mathrm{ppm}$ and $\left[\mathrm{O}_{3}\right]_{0, \mathrm{LFR}}$ to $300 \mathrm{ppm}$ additionally achieved $F_{\mathrm{VOC}+\mathrm{NO}_{3}} \geq 0.9$ for acenaphthylene, isoprene, and mono- and sesquiterpenes with one double bond at elevated $\mathrm{RH}_{\mathrm{OFR}}$. Further increasing $\left[\mathrm{NO}_{2}\right]_{0, \mathrm{LFR}}$ to $5400 \mathrm{ppm}$ and $\left[\mathrm{O}_{3}\right]_{0, \mathrm{LFR}}$ to $3000 \mathrm{ppm}$ achieved $F_{\mathrm{VOC}+\mathrm{NO}_{3}} \geq 0.9$ for $\geq \mathrm{C} 3$ linear alkenes, unsaturated aldehydes, and monoand sesquiterpenes with two double bonds at low $\mathrm{RH}_{\mathrm{OFR}}$. While $\left[\mathrm{NO}_{2}, \mathrm{O}_{3}\right]=[20 \%, 10 \%]$ (not shown) achieved $F_{\mathrm{VOC}+\mathrm{NO}_{3}} \geq 0.9$ for (E)-3-penten-2-one and ethene, the corresponding $\mathrm{NO}_{3 \exp } \approx 10^{14}$ molecules $\mathrm{cm}^{-3} \mathrm{~s}$ achieved at this condition (Fig. 7a) was insufficient to oxidize more than $1 \%-2 \%$ of the initial ethene concentration due to its slow $\mathrm{NO}_{3}$ rate constant (Atkinson, 1991).

\section{5 $\mathrm{NO}_{3}$ estimation equation for $\mathrm{OFR}-\mathrm{iN}_{2} \mathrm{O}_{5}$}

Previous studies reported empirical $\mathrm{OH}$ exposure algebraic estimation equations for use with OFRs (Li et al., 2015; Peng et al., 2015, 2018; Lambe et al., 2019). These equations parameterize $\mathrm{OH}_{\text {exp }}$ as a function of readily measured experimental parameters, thereby providing a simpler alternative to detailed photochemical models for experimental planning 


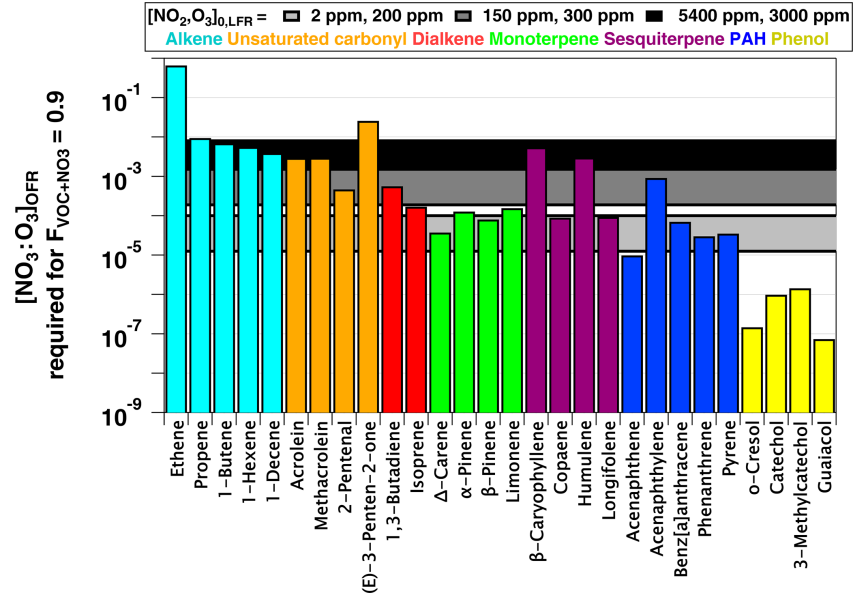

Figure 9. $\mathrm{NO}_{3}: \mathrm{O}_{3}$ at which $F_{\mathrm{VOC}+\mathrm{NO}_{3}}=0.9$ for representative VOCs with $k_{\mathrm{NO}_{3}}>10^{-16}$ and $k_{\mathrm{O}_{3}}>10^{-19} \mathrm{~cm}^{3}$ molecules ${ }^{-1} \mathrm{~s}^{-1}$ (Manion et al., 2015). Horizontal bands represent upper and lower limit values calculated assuming $k_{\mathrm{w}, \mathrm{N}_{2} \mathrm{O}_{5}}=0.01$ and $0.08 \mathrm{~s}^{-1}$.

and analysis. Here, we expand on those studies by deriving an $\mathrm{NO}_{3}$ exp estimation equation for OFR-i $\mathrm{N}_{2} \mathrm{O}_{5}$. Model results obtained from the base case of the model $-\mathrm{a}$ VOC reacting with $\mathrm{NO}_{3}$ at $2.5 \times 10^{-12} \mathrm{~cm}^{3}$ molecule ${ }^{-1} \mathrm{~s}^{-1}$ as a surrogate for $\mathrm{NO}_{3} \mathrm{R}_{\text {ext }}$ - were used to derive the following equation that allows for the estimation of $\mathrm{NO}_{3 \exp }$ for OFR$\mathrm{iN}_{2} \mathrm{O}_{5}$ :

$$
\begin{aligned}
\log & {\left[\left(\mathrm{NO}_{3}\right)_{\exp }\right]=a+b \log \left[273.15+T_{\mathrm{OFR}}\right]+c \log \left[\tau_{\mathrm{OFR}}\right] } \\
& +d \log \left[\mathrm{NO}_{2}\right]_{0, \mathrm{LFR}}+e \log \left[\mathrm{O}_{3}\right]_{0, \mathrm{LFR}} \cdot T_{\mathrm{OFR}} \\
& +f \log \left[k_{\mathrm{W}_{\mathrm{OFR}}, \mathrm{N}_{2} \mathrm{O}_{5}}\right]+\log \left(\frac{\left[\mathrm{NO}_{2}\right]_{0, \mathrm{LFR}}}{\left[\mathrm{O}_{3}\right]_{0, \mathrm{LFR}}}\right) \\
& \cdot\left(g\left(\log \left[\mathrm{O}_{3}\right]_{0, \mathrm{LFR}}\right)^{2}+h \log \left[\mathrm{O}_{3}\right]_{0, \mathrm{LFR}}\right)-\frac{\left[\mathrm{NO}_{2}\right]_{0, \mathrm{LFR}}}{\left[\mathrm{O}_{3}\right]_{0, \mathrm{LFR}}} \\
& \cdot\left(i+j \log \left[\mathrm{O}_{3}\right]_{0, \mathrm{LFR}}\right)+k \log \left(\mathrm{NO}_{3} \mathrm{R}\right)_{\mathrm{ext}} \\
& +l \log \left[\mathrm{NO}_{2}\right]_{0, \mathrm{LFR}} \cdot T+m \log \left[\mathrm{O}_{3}\right]_{0, \mathrm{LFR}} \cdot \log k_{\mathrm{W}_{\mathrm{OFR}}, \mathrm{N}_{2} \mathrm{O}_{5}}
\end{aligned}
$$

The phase space of OFR-iN $\mathrm{N}_{2} \mathrm{O}_{5}$ parameters for fitting Eq. (6) to the $\mathrm{NO}_{3} \exp$ model results was defined as follows: $\left[\mathrm{O}_{3}\right]_{0, \mathrm{LFR}}=10-1000 \mathrm{ppm},\left[\mathrm{NO}_{2}\right]_{0, \mathrm{LFR}}=$ $10-1000 \mathrm{ppm}, \quad\left[\mathrm{NO}_{2}\right]_{0, \mathrm{LFR}}:\left[\mathrm{O}_{3}\right]_{0, \mathrm{LFR}} \leq 2, \mathrm{NO}_{3} \mathrm{R}_{\mathrm{ext}}=1-$ $200 \mathrm{~s}^{-1}, k_{\mathrm{W}_{\mathrm{OFR}}, \mathrm{N}_{2} \mathrm{O}_{5}}=0.01-0.08 \mathrm{~s}^{-1}, T_{\mathrm{OFR}}=0-40^{\circ} \mathrm{C}$, and $\tau_{\mathrm{OFR}}=60-300 \mathrm{~s}$. The cases where $\left[\mathrm{O}_{3}\right]_{0, \mathrm{LFR}}>1000 \mathrm{ppm}$ and/or $\left[\mathrm{NO}_{2}\right]_{0, \text { LFR }}:\left[\mathrm{O}_{3}\right]_{0, \text { LFR }}>2$ were not considered due to less practical interest. We explored 11, 11, 7, 4, and 5 logarithmically evenly distributed values in the ranges of $\left[\mathrm{O}_{3}\right]_{0, \mathrm{LFR}},\left[\mathrm{NO}_{2}\right]_{0, \mathrm{LFR}}$ (11 values over $10-1000 \mathrm{ppm}$ ), $\mathrm{NO}_{3} \mathrm{R}_{\text {ext }}, k_{\mathrm{w}, \mathrm{N}_{2} \mathrm{O}_{5}}$, and $\tau_{\mathrm{OFR}}$, respectively. Due to significantly different chemical regimes in different parts of the phase space, fit coefficients that are reported in Table 1 were obtained by fitting the same functional form
Table 1. Fit parameters for $\mathrm{NO}_{3 \exp }$ estimation equation (Eq. 6)

\begin{tabular}{lrrr}
\hline Parameter & $\begin{array}{r}\text { Subspace 1 } \\
\text { values }\end{array}$ & $\begin{array}{r}\text { Subspace 2 } \\
\text { values }\end{array}$ & $\begin{array}{r}\text { Subspace 3 } \\
\text { values }\end{array}$ \\
\hline$a$ & 61.0694 & -59.3835 & 246.416 \\
$b$ & -20.1400 & 27.3434 & -122.229 \\
$c$ & 0.795209 & 0.803508 & 0.581443 \\
$d$ & -0.375825 & 1.18285 & 51.2355 \\
$e$ & 0.0311034 & 0.00815681 & -0.66569 \\
$f$ & 0.888193 & -0.0731138 & -0.0210958 \\
$g$ & -0.379009 & 0.13199 & -0.346062 \\
$h$ & 1.73605 & -0.422009 & -81.9221 \\
$i$ & 0.14737 & 0.035132 & -22.4373 \\
$j$ & 0.261402 & 0.311104 & 13.204 \\
$k$ & -1.22009 & -0.323329 & -0.118988 \\
$l$ & 0.00733645 & -0.004277 & 0.676436 \\
$m$ & -0.957064 & -0.436977 & -0.3983 \\
\hline
\end{tabular}

(Eq. 6) over three subphase spaces with the following additional constraints: (1) $\left[\mathrm{NO}_{2}\right]_{0, \mathrm{LFR}}:\left[\mathrm{O}_{3}\right]_{0, \mathrm{LFR}}=0-1$ and $\mathrm{NO}_{3} \mathrm{R}_{\mathrm{ext}}=20-200 \mathrm{~s}^{-1}$; (2) $\left[\mathrm{NO}_{2}\right]_{0, \mathrm{LFR}}:\left[\mathrm{O}_{3}\right]_{0, \mathrm{LFR}}=0-1$ and $\mathrm{NO}_{3} \mathrm{R}_{\mathrm{ext}}=1-20 \mathrm{~s}^{-1}$; and (3) $\left[\mathrm{NO}_{2}\right]_{0, \mathrm{LFR}}:\left[\mathrm{O}_{3}\right]_{0, \mathrm{LFR}}=$ $1-2$. For these three subspaces, 10080, 13440, and 5880 respective model cases were simulated. In Eq. (6), the terms involving the coefficients $g-j$ were included to reproduce the relationship between normalized $\mathrm{NO}_{3} \exp$ and $\left[\mathrm{NO}_{2}\right]_{0, \mathrm{LFR}}$ : $\left[\mathrm{O}_{3}\right]_{0, \mathrm{LFR}}$ shown in Fig. 5. Logarithms of first- and secondorder terms were successively added until no further fit quality improvement was achieved. Figure 10 compares $\mathrm{NO}_{3 \exp }$ estimated from Eq. (6) and calculated from the model described in Sect. 2.2. The mean absolute value of the relative deviation was $49 \%$ which is comparable to results obtained for previous estimation equations with significant $\mathrm{NO}_{y}$ chemistry (Peng et al., 2018).

$\mathrm{NO}_{3} R_{\text {ext }}$ of a system will change over the course of multiple generations of $\mathrm{NO}_{3}$ oxidation due to changes in kinetic rate coefficients between different species and $\mathrm{NO}_{3}$ $\left(k_{\mathrm{NO}_{3}}\right)$. The sensitivity of Eq. (6) to changes in $\mathrm{NO}_{3} \mathrm{R}_{\mathrm{ext}}$ depends in part on the relative magnitudes of $\mathrm{NO}_{3} \mathrm{R}_{\text {ext }}$ and the internal $\mathrm{NO}_{3}$ reactivity, $\mathrm{NO}_{3} \mathrm{R}_{\mathrm{int}}$, which is approximately equal to $k_{\mathrm{NO}_{2}+\mathrm{NO}_{3}}\left[\mathrm{NO}_{2}\right]$. If $\mathrm{NO}_{3} \mathrm{R}_{\text {int }} \gg \mathrm{NO}_{3} \mathrm{R}_{\text {ext }}$, changes in $\mathrm{NO}_{3} \mathrm{R}_{\text {ext }}$ would have minimal influence on Eq. (6). In one case study, we examined changes in $\mathrm{NO}_{3} \mathrm{R}_{\text {ext }}$ following conversion of biogenic VOCs (BVOCs) to gas-phase carbonyl oxidation products with known $k_{\mathrm{NO}_{3}}$ values. Table S5 compares $k_{\mathrm{NO}_{3}}$ of isoprene to methyl vinyl ketone and methacrolein, $\alpha$-pinene to pinonaldehyde, sabinene to sabinaketone, and 3-carene to caronaldehyde. At the limit where $100 \%$ of each BVOC is converted to its carbonyl oxidation product, $\mathrm{NO}_{3} \mathrm{R}_{\text {ext }}$ decreases by a factor of 200 or greater. Unsaturated organic nitrates that are generated from $\mathrm{BVOC}+\mathrm{NO}_{3}$ may also be reactive towards $\mathrm{NO}_{3}$, but $k_{\mathrm{NO}_{3}}$ for these species are not available. In another case study, we examined changes in $\mathrm{NO}_{3} \mathrm{R}_{\mathrm{ext}}$ following conversion of 
BVOCs to SOA. An effective $k_{\mathrm{NO}_{3}}$ for SOA was calculated using the following equation adapted from Lambe et al. (2009):

$k_{\mathrm{NO}_{3}}=\frac{3}{2} \frac{\gamma \times \bar{c} \times M_{\mathrm{SOA}} \times F_{\mathrm{diff}}}{D_{\mathrm{p}} \times \rho_{\mathrm{p}} \times N_{\mathrm{A}}}$,

where $F_{\text {diff }}$ is a correction factor accounting for diffusion limitations to the particle surface in the transition regime (Fuchs and Sutugin, 1970),

$$
F_{\text {diff }}=\frac{1+6 \times \frac{D_{\mathrm{NO}_{3}}}{\bar{c} \times D_{\mathrm{p}}}}{1+10.26 \times \frac{D_{\mathrm{NO}_{3}}}{\bar{c} \times D_{\mathrm{p}}}+47.88 \times\left(\frac{D_{\mathrm{NO}_{3}}}{\bar{c} \times D_{\mathrm{p}}}\right)^{2}} ;
$$

$\gamma$ is the fraction of collisions between $\mathrm{NO}_{3}$ and SOA resulting in reaction; $D_{\mathrm{p}}$ is the surface area-weighted mean particle diameter; $\rho_{\mathrm{p}}$ is the particle density; $N_{\mathrm{A}}$ is Avogadro's number; $\bar{c}$ is the mean molecular speed of $\mathrm{NO}_{3}\left(3.2 \times 10^{4} \mathrm{~cm} \mathrm{~s}^{-1}\right.$ at $T=298 \mathrm{~K}) ; M_{\mathrm{SOA}}$ is the mean molecular weight of the $\mathrm{SOA}$; and $D_{\mathrm{NO}_{3}}=0.08 \mathrm{~cm}^{2} \mathrm{~s}^{-1}$ is the $\mathrm{NO}_{3}$ diffusion coefficient in air (Rudich et al., 1996). Figure $\mathrm{S} 4$ shows $k_{\mathrm{SOA}+\mathrm{NO}_{3}}$ as a function of $D_{\mathrm{p}}$ ranging from 1 to $1000 \mathrm{~nm}$, assuming $\rho_{\mathrm{p}}=1.4 \mathrm{~g} \mathrm{~cm}^{-3}, M_{\mathrm{SOA}}=250 \mathrm{~g} \mathrm{~mol}^{-1}$ (Nah et al., 2016), and an upper limit $\gamma=0.1$ for BVOC-derived SOA ( $\mathrm{Ng}$ et al., 2017). For reference, the range of slowest (isoprene) and fastest (humulene) known $k_{\mathrm{BVOC}+\mathrm{NO}_{3}}$ are indicated by the vertical blue line on the $y$ axis. At the limit where $100 \%$ of a BVOC is converted to $\mathrm{SOA}, \mathrm{NO}_{3} \mathrm{R}_{\text {ext }}$ decreases by a factor of 10 or greater depending on $k_{\mathrm{BVOC}+\mathrm{NO}_{3}}$ and $D_{\mathrm{p}}$. Taken together, these results suggest that $\mathrm{NO}_{3} \mathrm{R}_{\text {ext }}$ decreases following $\mathrm{NO}_{3}$ oxidation of BVOCs to carbonyl oxidation products and/or SOA. In this case, inputting $\mathrm{NO}_{3} \mathrm{R}_{\text {ext }}$ of the BVOC precursor to Eq. (6) generates a lower limit to $\mathrm{NO}_{3} \exp$ over multiple generations of $\mathrm{NO}_{3}$ oxidation. Results for other systems will depend on the $k_{\mathrm{NO}_{3}}$ values of associated gasand condensed-phase precursors and their oxidation products.

\subsection{SOA generation from $\beta$-pinene $+\mathrm{NO}_{3}$}

To apply the OFR-iN $\mathrm{N}_{2} \mathrm{O}_{5}$ technique to SOA formation studies, we generated SOA from $\beta$-pinene $+\mathrm{NO}_{3}$ in the absence of seed particles using $\left[\mathrm{O}_{3}\right]_{0, \mathrm{LFR}}=300 \mathrm{ppm},\left[\mathrm{NO}_{2}\right]_{0, \mathrm{LFR}}=$ $150 \mathrm{ppm}$, and $\mathrm{RH}_{\mathrm{OFR}} \approx 1 \%$. PTR-MS measurements confirmed the complete consumption of $\beta$-pinene, and numerous product ions were detected. The largest ions detected were $\left(\mathrm{H}^{+}\right) \mathrm{C}_{9} \mathrm{H}_{14} \mathrm{O}$ and $\left(\mathrm{H}^{+}\right) \mathrm{C}_{10} \mathrm{H}_{14}$ which may correspond to nopinone $\left(\mathrm{C}_{9} \mathrm{H}_{14} \mathrm{O}\right)$ and fragmentation or decomposition products of $\mathrm{C}_{10} \mathrm{H}_{17} \mathrm{NO}_{4}$, respectively (Hallquist et al., 1999; Claflin and Ziemann, 2018). The mass yield of SOA ranged from 0.03 to 0.39 over $\beta$-pinene mixing ratios ranging from 20 to $400 \mathrm{ppbv}$ that were injected into the OFR. These yield values are broadly consistent with previous environmental chamber studies ( $\mathrm{Ng}$ et al., 2017) but are lower than chamber SOA yields obtained at the same $\beta$-pinene mixing ratio,

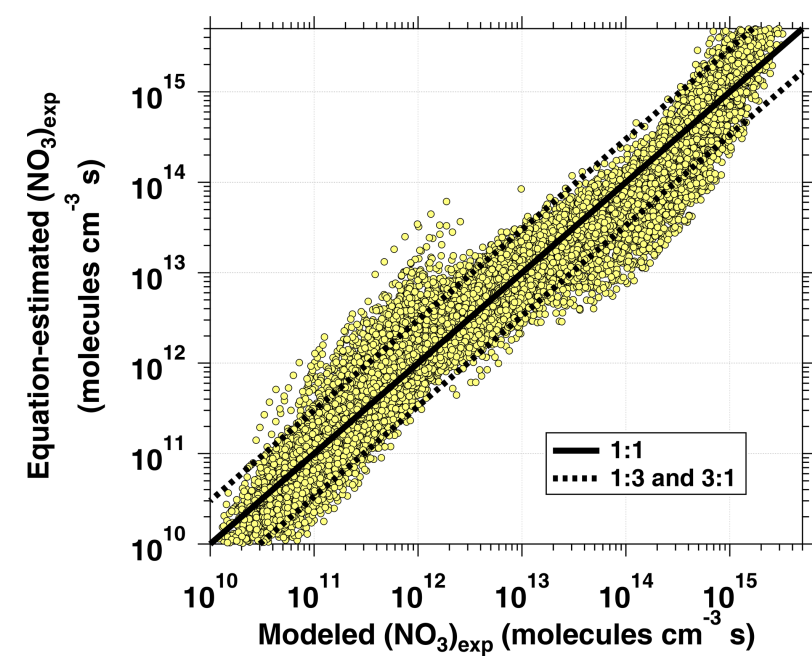

Figure 10. $\mathrm{NO}_{3 \exp }$ calculated from the estimation equation (Eq. 6 and Table 1) as a function of $\mathrm{NO}_{3 \exp }$ calculated from the full OFR$\mathrm{iN}_{2} \mathrm{O}_{5}$ KinSim mechanism (Table S2). Solid and dashed lines correspond to the $1: 1$ and the $1: 3$, and $3: 1$ lines, respectively.

presumably due to the absence of seed particles in the OFR (Lambe et al., 2015). To compare the results obtained using OFR-i $\mathrm{N}_{2} \mathrm{O}_{5}$ with a conventional environmental chamber method, Fig. 11a and b show HR-ToF-AMS spectra of SOA generated from $\mathrm{NO}_{3}$ oxidation of $\beta$-pinene in the Georgia Tech chamber (Boyd et al., 2015) and in the OFR, along with a scatter plot of relative ion abundances present in the two spectra (Fig. 11c). The same spectra are presented on a logarithmic scale in Fig. S5. As is evident, $\beta$-pinene $+\mathrm{NO}_{3} \mathrm{SOA}$ generated in the chamber and OFR exhibit a high degree of similarity (linear regression slope $=0.98$ and $r^{2}=0.99$ ). The largest ion signal was observed at $\mathrm{NO}^{+}$, which, along with the signal at $\mathrm{NO}_{2}^{+}$and $\mathrm{NO}^{+}: \mathrm{NO}_{2}^{+}=6.7$, is consistent with the formation of particulate organic nitrates (Farmer et al., 2010). Signals observed at $\mathrm{CHO}^{+}, \mathrm{C}_{2} \mathrm{H}_{3} \mathrm{O}^{+}$, and other $\mathrm{C}_{x} \mathrm{H}_{y} \mathrm{O}_{>1}^{+}$ions suggest the presence of other multifunctional oxidation products.

\section{Conclusions}

OFR-iN $\mathrm{N}_{2} \mathrm{O}_{5}$ complements recently developed methods that enable $\mathrm{NO}_{x}$-dependent photooxidation studies in OFRs such as OFR-i $\mathrm{N}_{2} \mathrm{O}$ and $\mathrm{OFR}-\mathrm{iC}_{3} \mathrm{H}_{7} \mathrm{ONO}$ (Lambe et al., 2017; Peng et al., 2018; Lambe et al., 2019) by enabling studies of nighttime $\mathrm{NO}_{3}$-initiated oxidative aging processes. Important OFR-i $\mathrm{N}_{2} \mathrm{O}_{5}$ parameters are $\left[\mathrm{O}_{3}\right],\left[\mathrm{NO}_{2}\right],\left[\mathrm{H}_{2} \mathrm{O}\right], T$, $\mathrm{NO}_{3} \mathrm{R}_{\mathrm{ext}}$, and $\tau_{\mathrm{OFR}}$. By contrast, important OFR-iN $\mathrm{N}_{2} \mathrm{O}$ and OFR-iC $\mathrm{C}_{3} \mathrm{H}_{7} \mathrm{ONO}$ parameters are UV intensity, external $\mathrm{OH}$ reactivity $\left(\mathrm{OHR}_{\text {ext }}\right), \tau_{\mathrm{OFR}}$, and either $\left[\mathrm{O}_{3}\right]+\left[\mathrm{H}_{2} \mathrm{O}\right]+\left[\mathrm{N}_{2} \mathrm{O}\right]$ or $\left[\mathrm{C}_{3} \mathrm{H}_{7} \mathrm{ONO}\right]$. Notably, $\mathrm{NO}_{3} \mathrm{R}_{\text {ext }}$ is typically less significant in OFR-i $\mathrm{iN}_{2} \mathrm{O}_{5}$ than $\mathrm{OHR}_{\text {ext }}$ in OFR-i $\mathrm{N}_{2} \mathrm{O}$ or OFR$\mathrm{iC}_{3} \mathrm{H}_{7} \mathrm{ONO}$ because (1) most compounds are less reactive 

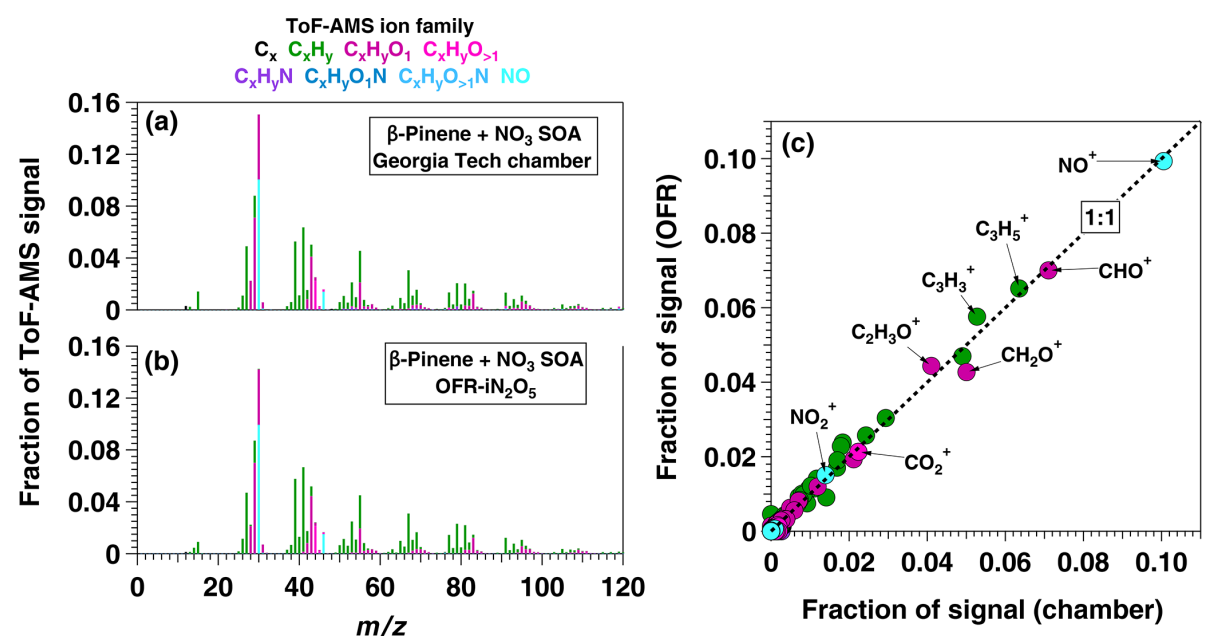

Figure 11. AMS spectra of SOA generated from $\mathrm{NO}_{3}$ oxidation of $\beta$-pinene in (a) the Georgia Tech environmental chamber (Boyd et al., 2015) and (b) OFR-iN $\mathrm{O}_{5}$. The scatter plot in (c) shows spectra generated in the OFR and in the chamber plotted against each other.

towards $\mathrm{NO}_{3}$ than $\mathrm{OH}$; (2) $\mathrm{NO}_{3}$ exp is higher than $\mathrm{OH}_{\text {exp }}$; and (3) $\left(\mathrm{NO}_{3} \mathrm{R}\right)_{\text {int }}$ of OFR-i $\mathrm{N}_{2} \mathrm{O}_{5}$, which is dominated by the $\mathrm{NO}_{3}+\mathrm{NO}_{2}$ reaction, is larger and easier to manipulate than the internal $\mathrm{OH}$ reactivity of OFR-i $\mathrm{N}_{2} \mathrm{O}$ and OFR$\mathrm{iC}_{3} \mathrm{H}_{7} \mathrm{ONO}$, which is dominated by $\mathrm{OH}+\mathrm{HO}_{2}$ and $\mathrm{OH}+$ $\mathrm{NO}_{2}$ reactions. To identify optimal OFR-i $\mathrm{N}_{2} \mathrm{O}_{5}$ conditions for different applications, we characterized $\mathrm{NO}_{3 \exp }, \tau_{\mathrm{RO}_{2}}$, $F_{\mathrm{RO}_{2}+\mathrm{NO}_{3}}, F_{\mathrm{R}+\mathrm{O}_{2}}$, and $F_{\mathrm{VOC}+\mathrm{NO}_{3}}$ at $\left[\mathrm{O}_{3}\right]_{0, \mathrm{LFR}}=10 \mathrm{ppm}$ to $10 \%,\left[\mathrm{NO}_{2}\right]_{0, \mathrm{LFR}}:\left[\mathrm{O}_{3}\right]_{0, \mathrm{LFR}}=0.01$ to 2.0 , and $\mathrm{RH}_{\mathrm{OFR}}=$ $7 \%$ to $85 \%$. Optimal $\mathrm{NO}_{3 \exp }$ was achieved by minimizing $\left[\mathrm{H}_{2} \mathrm{O}\right]$ in the OFR and associated humidity-dependent $\mathrm{N}_{2} \mathrm{O}_{5}$ wall losses. This is contrary to most OFR techniques that are used to generate $\mathrm{OH}$ radicals, where optimal $\mathrm{OH}_{\text {exp }}$ is achieved by maximizing $\left[\mathrm{H}_{2} \mathrm{O}\right]$ and the associated $\mathrm{OH}$ production from the $\mathrm{O}\left({ }^{1} \mathrm{D}\right)+\mathrm{H}_{2} \mathrm{O}$ reaction and/or $\mathrm{H}_{2} \mathrm{O}$ photolysis at $\lambda=185 \mathrm{~nm}$.

Figure 12 presents image plots that represent OFR-iN $\mathrm{O}_{2}$ conditions suitable for generating optimal $\mathrm{NO}_{3} \exp , \mathrm{NO}_{3}: \mathrm{O}_{3}$, $\mathrm{NO}_{2}: \mathrm{NO}_{3}$, and $\tau_{\mathrm{RO}_{2}}$ values at the lower and upper limit $k_{\mathrm{w}, \mathrm{N}_{2} \mathrm{O}_{5}}$ values that were measured. Most OFR-i $\mathrm{N}_{2} \mathrm{O}_{5}$ conditions using $\left[\mathrm{O}_{3}\right]_{0, \mathrm{LFR}}>200 \mathrm{ppm}$ generated $\mathrm{NO}_{3} \exp >1.5 \times$ $10^{12}$ molecules $\mathrm{cm}^{-3} \mathrm{~s}$ (Fig. 12a, b), which is sufficient to oxidize isoprene and compounds with similar $k_{\mathrm{NO}_{3}}$; for reference, $\mathrm{NO}_{3 \exp }>1.6 \times 10^{11}$ molecules $\mathrm{cm}^{-3} \mathrm{~s}$ is required to oxidize $\alpha$-pinene. At $\left[\mathrm{O}_{3}\right]_{0, \mathrm{LFR}}>200 \mathrm{ppm}$ and $\left[\mathrm{NO}_{2}\right]_{0, \mathrm{LFR}}$ : $\left[\mathrm{O}_{3}\right]_{0, \mathrm{LFR}}>0.5$, OFR-iN $\mathrm{O}_{5}$ generated $\mathrm{NO}_{3}: \mathrm{O}_{3}>10^{-3}$ at $k_{\mathrm{w}, \mathrm{N}_{2} \mathrm{O}_{5}}=0.01 \mathrm{~s}^{-1}$ (Fig. 12c), which achieved $F_{\mathrm{VOC}+\mathrm{NO}_{3}}>$ 0.9 for mono- and sesquiterpenes with one double bond, most PAHs, and phenol/methoxyphenol species. Achiev-

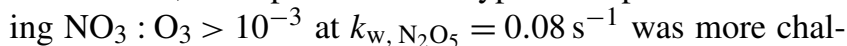
lenging (Fig. 12d). Increasing $\left[\mathrm{O}_{3}\right]_{0, \mathrm{LFR}}$ decreased $\left[\mathrm{NO}_{2}\right]$ : $\left[\mathrm{NO}_{3}\right]$ and, therefore, increased $F_{\mathrm{RO}_{2}+\mathrm{NO}_{3}}$ (Fig. 12e, f). In contrast, decreasing $\left[\mathrm{O}_{3}\right]_{0, \mathrm{LFR}}$ or increasing $k_{\mathrm{w}, \mathrm{N}_{2} \mathrm{O}_{5}}$, and, consequently, $\mathrm{NO}_{3 \exp }$, increased $\tau_{\mathrm{RO}_{2}}$ (Fig. $12 \mathrm{~g}$, h), potentially allowing more time for the autooxidation processes

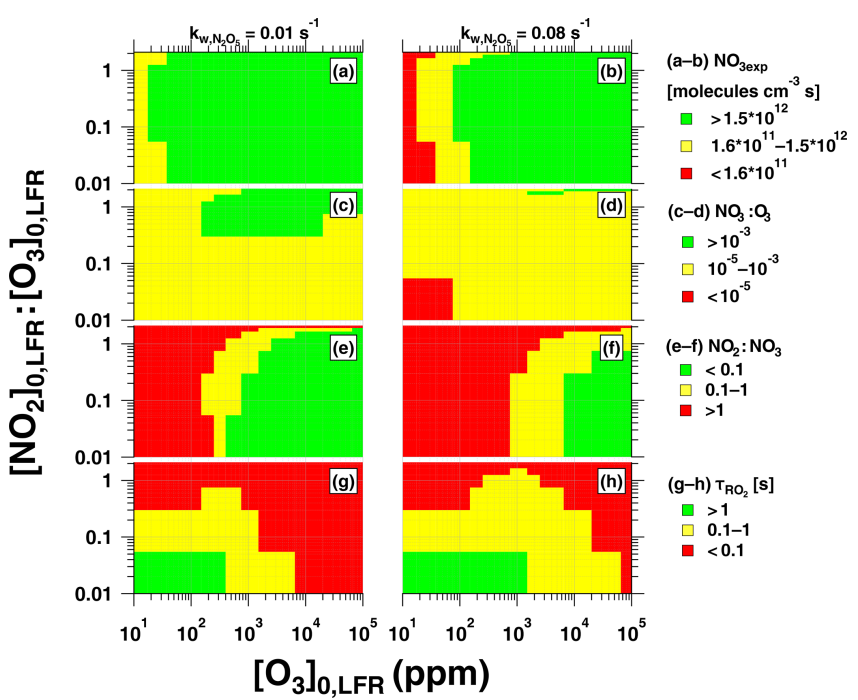

Figure 12. Summary of OFR-i $\mathrm{N}_{2} \mathrm{O}_{5}$ operating conditions suitable for maximum $(\mathbf{a}, \mathbf{b}) \mathrm{NO}_{3} \exp ,(\mathbf{c}, \mathbf{d}) \mathrm{NO}_{3}: \mathrm{O}_{3},(\mathbf{e}, \mathbf{f}) \mathrm{NO}_{2}: \mathrm{NO}_{3}$,

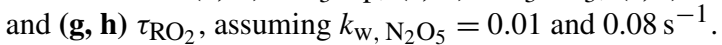

to occur. The best overlap between OFR-i $\mathrm{N}_{2} \mathrm{O}_{5}$ conditions that achieved $F_{\mathrm{RO}_{2}+\mathrm{NO}_{3}}>0.9$ and $\tau_{\mathrm{RO}_{2}}>1 \mathrm{~s}$ was obtained with $\left[\mathrm{NO}_{2}\right]_{0, \mathrm{LFR}} \approx 2-3 \mathrm{ppm}$ and $\left[\mathrm{O}_{3}\right]_{0, \mathrm{LFR}} \approx 200-300 \mathrm{ppm}$. Because atmospheric $\mathrm{NO}_{2}: \mathrm{NO}_{3}$ is highly variable and often much larger than $\mathrm{NO}_{2}: \mathrm{NO}_{3}$ achieved using OFR-iN $\mathrm{O}_{2}$ (Brown et al., 2003; Stutz et al., 2004), simply attempting to maximize $F_{\mathrm{RO}_{2}+\mathrm{NO}_{3}}$ may not always be necessary and has trade-offs such as decreasing $\mathrm{NO}_{3}: \mathrm{O}_{3}$ and $F_{\mathrm{VOC}+\mathrm{NO}_{3}}$. OFR$\mathrm{iN}_{2} \mathrm{O}_{5}$ was more difficult to apply to species such as unsaturated carbonyls and mono- and sesquiterpenes with multiple double bonds that react more efficiently with $\mathrm{O}_{3}$ than other VOCs; here, alternative $\mathrm{NO}_{3}$ generation techniques that do not introduce $\mathrm{O}_{3}$ to the OFR warrant consideration, even 
though they are more difficult to implement (Palm et al., 2017).

Because OFR-iN $\mathrm{N}_{2} \mathrm{O}_{5}$ can continuously generate $\mathrm{N}_{2} \mathrm{O}_{5}$ and $\mathrm{NO}_{3}$ at room temperature, it is significantly easier to apply in continuous flow reactor studies than related techniques. However, in addition to the aforementioned considerations, high $\mathrm{N}_{2} \mathrm{O}_{5}$ and $\mathrm{HNO}_{3}$ concentrations that are generated using OFR- $\mathrm{iN}_{2} \mathrm{O}_{5}$ complicate the application of techniques such as iodide-adduct chemical ionization mass spectrometry due to efficient reactions between the iodide reagent ion and $\mathrm{N}_{2} \mathrm{O}_{5}$ or $\mathrm{HNO}_{3}$ (Lee et al., 2014). Additionally, the humidity-dependent $\mathrm{N}_{2} \mathrm{O}_{5}$ wall loss rate must be accurately characterized to model the performance of a specific OFR$\mathrm{iN}_{2} \mathrm{O}_{5}$ configuration. Future applications of $\mathrm{OFR}-\mathrm{iN}_{2} \mathrm{O}_{5}$ will investigate the $\mathrm{NO}_{3}$-initiated OVOC and SOA formation potential of simple and complex precursors in laboratory and field studies.

Code and data availability. Data and KinSim mechanisms presented in this paper are available upon request. The KinSim kinetic solver is freely available at http://tinyurl.com/kinsim-release (Peng and Jimenez, 2020).

Supplement. The supplement related to this article is available online at: https://doi.org/10.5194/amt-13-2397-2020-supplement.

Author contributions. ATL, ECW, and AA conceived and planned the experiments. ATL, JEK, FM, LRW, PLC, AA, and JEP carried out the experiments. MC and AF performed the IBBCEAS measurements and data analysis. AL, JLJ, and ZP conceived and planned the model simulations, and ATL and ZP carried out the model simulations. ATL, ECW, ZP, and JLJ contributed to the interpretation of the results. AL took the lead in writing the paper. All authors provided feedback on the paper.

Competing interests. The authors declare no competing interests.

Acknowledgements. Andrew T. Lambe thanks Christopher Boyd and Sally Ng (Georgia Tech) for sharing AMS data obtained in their environmental chamber, and the following colleagues for helpful discussions: Megan Claflin, Manjula Canagaratna, John Jayne, and Douglas Worsnop from ARI; William Brune from Pennsylvania State University; Manfred Winnewisser from Ohio State University; Karl Christe from the University of Southern California; and Robert Woodward-Massey, Youfeng Wang, and Chunxiang Ye from Peking University. The authors thank the ACMCC and participants of the ACMCC $p$ ON experiment in December 2018.

Financial support. The ACMCC $p \mathrm{ON}$ experiment was supported by the French Ministry of Environment and part of the COST Action CA16109 COLOSSAL and the Aerosol, Clouds, and Trace gases Research InfraStructure (ACTRIS). Zhe Peng and Jose L. Jimenez were supported by the US NSF (grant no. AGS-1822664) and EPA STAR (grant no. 83587701-0). This paper has not been reviewed by the EPA and no endorsement should be inferred.

Review statement. This paper was edited by Keding Lu and reviewed by three anonymous referees.

\section{References}

Albinet, A., Petit, J.-E., Lambe, A. T., Kalogridis, A., Heikkinen, L., Graeffe, F., Cirtog, M., Féron, A., Allan, J. D., Bibi, Z., Amodeo, T., Karoski, N., Aujay-Plouzeau, R., Meunier, L., Gros, V., Bonnaire, N., Sarda-Estève, R., Truong, F., Ehn, M., Jokinen, T., Aurela, M., Maasikmets, M., Marin, C., Marmureanu, L., Eriksson, A., Ahlberg, E., Freney, E., Minguillon, M., Croteau, P. L., Jayne, J. T., Williams, L. R., and Favez, O.: Overview of the ACMCC particulate organonitrates $(p \mathrm{ON})$ experiment, in: 37th AAAR Conference, 14-18 October 2019, Portland, OR, USA, 2019.

Asaf, D., Tas, E., Pedersen, D., Peleg, M., and Luria, M.: LongTerm Measurements of $\mathrm{NO}_{3}$ Radical at a Semiarid Urban Site: 2 . Seasonal Trends and Loss Mechanisms, Environ. Sci. Technol., 44, 5901-5907, https://doi.org/10.1021/es100967z, 2010.

Atkinson, R.: Kinetics and Mechanisms of the Gas-Phase Reactions of the $\mathrm{NO}_{3}$ Radical with Organic Compounds, J. Phys. Chem. Ref. Data, 20, 459-507, https://doi.org/10.1063/1.555887, 1991.

Atkinson, R., Arey, J., Zielinska, B., and Aschmann, S. M.: Kinetics and nitro-products of the gas-phase $\mathrm{OH}$ and $\mathrm{NO}_{3}$ radical-initiated reactions of naphthalene- $\mathrm{d}_{8}$, fluoranthene- $\mathrm{d}_{10}$, and pyrene, Int. J. Chem., 22, 999-1014, https://doi.org/10.1002/kin.550220910, 1990.

Atkinson, R., Tuazon, E. C., Bridier, I., and Arey, J.: Reactions of $\mathrm{NO}_{3}$-naphthalene adducts with $\mathrm{O}_{2}$ and $\mathrm{NO}_{2}$, Int. J. Chem. Kinet., 26, 605-614, https://doi.org/10.1002/kin.550260603, 1994.

Berndt, T., Mentler, B., Scholz, W., Fischer, L., Herrmann, H., Kulmala, M., and Hansel, A.: Accretion Product Formation from Ozonolysis and $\mathrm{OH}$ Radical Reaction of $\alpha$ Pinene: Mechanistic Insight and the Influence of Isoprene and Ethylene, Environ. Sci. Technol., 52, 11069-11077, https://doi.org/10.1021/acs.est.8b02210, 2018a.

Berndt, T., Scholz, W., Mentler, B., Fischer, L., Herrmann, H., Kulmala, M., and Hansel, A.: Accretion Product Formation from Self- and Cross-Reactions of $\mathrm{RO}_{2}$ Radicals in the Atmosphere, Angew. Chem. Int. Ed., 57, 3820-3824, https://doi.org/10.1002/anie.201710989, 2018b.

Boyd, C. M., Sanchez, J., Xu, L., Eugene, A. J., Nah, T., Tuet, W. Y., Guzman, M. I., and Ng, N. L.: Secondary organic aerosol formation from the $\beta$-pinene $+\mathrm{NO}_{3}$ system: effect of humidity and peroxy radical fate, Atmos. Chem. Phys., 15, 7497-7522, https://doi.org/10.5194/acp-15-7497-2015, 2015.

Brown, S. S. and Stutz, J.: Nighttime radical observations and chemistry, Chem. Soc. Rev., 41, 6405-6447, https://doi.org/10.1039/C2CS35181A, 2012.

Brown, S. S., Stark, H., Ryerson, T. B., Williams, E. J., Nicks Jr., D. K., Trainer, M., Fehsenfeld, F. C., and Ravishankara, A. R.: 
Nitrogen oxides in the nocturnal boundary layer: Simultaneous in situ measurements of $\mathrm{NO}_{3}, \mathrm{~N}_{2} \mathrm{O}_{5}, \mathrm{NO}_{2}, \mathrm{NO}$, and $\mathrm{O}_{3}$, J. Geophys. Res., 108, 4299, https://doi.org/10.1029/2002jd002917, 2003.

Burrows, J. P., Tyndall, G. S., and Moortgat, G. K.: Absorption spectrum of $\mathrm{NO}_{3}$ and kinetics of the reactions of $\mathrm{NO}_{3}$ with $\mathrm{NO}_{2}$, $\mathrm{Cl}$, and several stable atmospheric species at $298 \mathrm{~K}$, J. Phys. Chem., 89, 4848-4856, https://doi.org/10.1021/j100268a038, 1985.

Cabañas, B., Baeza, M. T., MartÍn, P., Salgado, S., Villanueva, F., Monedero, E., and Wirtz, K.: Products and Mechanism of the $\mathrm{NO}_{3}$ Reaction with Thiophene, J. Atmos. Chem., 51, 317-335, https://doi.org/10.1007/s10874-005-3580-5, 2005.

Cirtog, M., Fouqueau, A., Michoud, V., Cazaunau, M., Bergé, A., Maisonneuve, F., Zapf, P., Pangui, E., Landsheere, X., Giacomoni, J., Gobbi, M., Hannotel, L., Paris, A., Roulier, N., Mellouki, A., Formenti, P., Cantrell, C., Doussin, J.-F., and PicquetVarralut, B.: Development of a Broad Band Cavity Enhanced Absorption Spectrometer for $\mathrm{NO}_{3}$ measurements on field and first observations of nighttime $\mathrm{NO}_{3}$ vertical profils over Paris, Atmos. Meas. Tech. Discuss., manuscript in preparation, 2020.

Claflin, M. S. and Ziemann, P. J.: Identification and Quantitation of Aerosol Products of the Reaction of beta-Pinene with $\mathrm{NO}_{3}$ Radicals and Implications for Gas- and Particle-Phase Reaction Mechanisms, J. Phys. Chem. A, 122, 3640-3652, https://doi.org/10.1021/acs.jpca.8b00692, 2018.

Crounse, J. D., Nielsen, L. B., Jørgensen, S., Kjaergaard, H. G., and Wennberg, P. O.: Autoxidation of Organic Compounds in the Atmosphere, J. Phys. Chem. Lett., 4, 3513-3520, 2013.

D’Anna, B., Andresen, Ø., Gefen, Z., and Nielsen, C. J.: Kinetic study of $\mathrm{OH}$ and $\mathrm{NO}_{3}$ radical reactions with 14 aliphatic aldehydes, Phys. Chem. Chem. Phys., 3, 3057-3063, https://doi.org/10.1039/B103623H, 2001.

Dubé, W. P., Brown, S. S., Osthoff, H. D., Nunley, M. R., Ciciora, S. J., Paris, M. W., McLaughlin, R. J., and Ravishankara, A. R.: Aircraft instrument for simultaneous, in situ measurement of $\mathrm{NO}_{3}$ and $\mathrm{N}_{2} \mathrm{O}_{5}$ via pulsed cavity ring-down spectroscopy, Rev. Sci., 77, 34-101, https://doi.org/10.1063/1.2176058, 2006.

Farmer, D. K., Matsunaga, A., Docherty, K. S., Surratt, J. D., Seinfeld, J. H., Ziemann, P. J., and Jimenez, J. L.: Atmospheric Chemistry Special Feature: Response of an aerosol mass spectrometer to organonitrates and organosulfates and implications for atmospheric chemistry, P. Natl. Acad. Sci. USA, 107, 6670$6675,2010$.

Fiedler, S. E., Hese, A., and Ruth, A. A.: Incoherent broad-band cavity-enhanced absorption spectroscopy, Chem. Phys. Lett., 371, 284-294, 2003.

Finlayson-Pitts, B. J. and Pitts Jr., J. N.: Chemistry of the Upper and Lower Atmosphere: Theory, Experiments, and Applications, Academic Press, Cambridge, Massachusetts, US, 2000.

Fouqueau, A., Cirtog, M., Cazaunau, M., Pangui, E., Zapf, P., Siour, G., Landsheere, X., Méjean, G., Romanini, D., and PicquetVarrault, B.: Implementation of an IBBCEAS technique in an atmospheric simulation chamber for in situ $\mathrm{NO}_{3}$ monitoring: characterization and validation for kinetic studies, Atmos. Meas. Tech. Discuss., https://doi.org/10.5194/amt-2020-103, in review, 2020.

Fuchs, N. A. and Sutugin, A. G.: Highly Dispersed Aerosols, Ann Arbor Science Publishers, Newton, MA, 1970.
Gržinić, G., Bartels-Rausch, T., Berkemeier, T., Türler, A., and Ammann, M.: Viscosity controls humidity dependence of $\mathrm{N}_{2} \mathrm{O}_{5}$ uptake to citric acid aerosol, Atmos. Chem. Phys., 15, 1361513625, https://doi.org/10.5194/acp-15-13615-2015, 2015.

Hallquist, M., Wängberg, I., Ljungström, E., Barnes, I., and Becker, K.-H.: Aerosol and Product Yields from $\mathrm{NO}_{3}$ Radical-Initiated Oxidation of Selected Monoterpenes, Environ. Sci. Technol., 33, 553-559, https://doi.org/10.1021/es980292s, 1999.

Jenkin, M. E., Saunders, S. M., Wagner, V., and Pilling, M. J.: Protocol for the development of the Master Chemical Mechanism, MCM v3 (Part B): tropospheric degradation of aromatic volatile organic compounds, Atmos. Chem. Phys., 3, 181-193, https://doi.org/10.5194/acp-3-181-2003, 2003.

Kang, E., Root, M. J., Toohey, D. W., and Brune, W. H.: Introducing the concept of Potential Aerosol Mass (PAM), Atmos. Chem. Phys., 7, 5727-5744, https://doi.org/10.5194/acp-7-5727-2007, 2007.

Kennedy, O. J., Ouyang, B., Langridge, J. M., Daniels, M. J. S., Bauguitte, S., Freshwater, R., McLeod, M. W., Ironmonger, C., Sendall, J., Norris, O., Nightingale, R., Ball, S. M., and Jones, R. L.: An aircraft based three channel broadband cavity enhanced absorption spectrometer for simultaneous measurements of $\mathrm{NO}_{3}, \mathrm{~N}_{2} \mathrm{O}_{5}$ and $\mathrm{NO}_{2}$, Atmos. Meas. Tech., 4, 1759-1776, https://doi.org/10.5194/amt-4-1759-2011, 2011.

Knopf, D. A., Forrester, S. M., and Slade, J. H.: Heterogeneous oxidation kinetics of organic biomass burning aerosol surrogates by $\mathrm{O}_{3}, \mathrm{NO}_{2}, \mathrm{~N}_{2} \mathrm{O}_{5}$, and $\mathrm{NO}_{3}$, Phys. Chem. Chem. Phys., 13, 21050-21062, https://doi.org/10.1039/C1CP22478F, 2011.

Krechmer, J., Lopez-Hilfiker, F., Koss, A., Hutterli, M., Stoermer, C., Deming, B., Kimmel, J., Warneke, C., Holzinger, R., Jayne, J., Worsnop, D., Fuhrer, K., Gonin, M., and de Gouw, J.: Evaluation of a New Reagent-Ion Source and Focusing Ion-Molecule Reactor for Use in Proton-TransferReaction Mass Spectrometry, Anal. Chem., 90, 12011-12018, https://doi.org/10.1021/acs.analchem.8b02641, 2018.

Lambe, A., Miracolo, M., Hennigan, C., Robinson, A., and Donahue, N.: Effective Rate Constants and Uptake Coefficients for the Reactions of Organic Molecular Markers (n-Alkanes, Hopanes, and Steranes) in Motor Oil and Diesel Primary Organic Aerosols with Hydroxyl Radicals, Environ. Sci. Technol., 43, 8794-8800, 2009.

Lambe, A. T., Ahern, A. T., Williams, L. R., Slowik, J. G., Wong, J. P. S., Abbatt, J. P. D., Brune, W. H., Ng, N. L., Wright, J. P., Croasdale, D. R., Worsnop, D. R., Davidovits, P., and Onasch, T. B.: Characterization of aerosol photooxidation flow reactors: heterogeneous oxidation, secondary organic aerosol formation and cloud condensation nuclei activity measurements, Atmos. Meas. Tech., 4, 445-461, https://doi.org/10.5194/amt-4445-2011, 2011.

Lambe, A. T., Chhabra, P. S., Onasch, T. B., Brune, W. H., Hunter, J. F., Kroll, J. H., Cummings, M. J., Brogan, J. F., Parmar, Y., Worsnop, D. R., Kolb, C. E., and Davidovits, P.: Effect of oxidant concentration, exposure time, and seed particles on secondary organic aerosol chemical composition and yield, Atmos. Chem. Phys., 15, 3063-3075, https://doi.org/10.5194/acp15-3063-2015, 2015.

Lambe, A., Massoli, P., Zhang, X., Canagaratna, M., Nowak, J., Daube, C., Yan, C., Nie, W., Onasch, T., Jayne, J., Kolb, C., Davidovits, P., Worsnop, D., and Brune, W.: Controlled nitric 
oxide production via $\mathrm{O}\left({ }^{1} \mathrm{D}\right)+\mathrm{N}_{2} \mathrm{O}$ reactions for use in oxidation flow reactor studies, Atmos. Meas. Tech., 10, 2283-2298, https://doi.org/10.5194/amt-10-2283-2017, 2017.

Lambe, A. T., Krechmer, J. E., Peng, Z., Casar, J. R., Carrasquillo, A. J., Raff, J. D., Jimenez, J. L., and Worsnop, D. R.: $\mathrm{HO}_{x}$ and $\mathrm{NO}_{x}$ production in oxidation flow reactors via photolysis of isopropyl nitrite, isopropyl nitrite- $\mathrm{d}_{7}$, and 1,3-propyl dinitrite at $\lambda=254$, 350, and $369 \mathrm{~nm}$, Atmos. Meas. Tech., 12, 299-311, https://doi.org/10.5194/amt-12-299-2019, 2019.

Langridge, J. M., Ball, S. M., Shillings, A. J. L., and Jones, R. L.: A broadband absorption spectrometer using light emitting diodes for ultrasensitive, in situ trace gas detection, Rev. Sci., 79, 123110, https://doi.org/10.1063/1.3046282, 2008.

Lee, B. H., Lopez-Hilfiker, F. D., Mohr, C., Kurten, T., Worsnop, D. R., and Thornton, J. A.: An Iodide-Adduct High-Resolution Time-of-Flight Chemical-Ionization Mass Spectrometer: Application to Atmospheric Inorganic and Organic Compounds, Environ. Sci. Technol., 48, 6309-6317, 2014.

Li, R., Palm, B. B., Ortega, A. M., Hlywiak, J., Hu, W., Peng, Z., Day, D. A., Knote, C., Brune, W. H., De Gouw, J. A., and Jimenez, J. L.: Modeling the Radical Chemistry in an Oxidation Flow Reactor: Radical Formation and Recycling, Sensitivities, and the $\mathrm{OH}$ Exposure Estimation Equation, J. Phys. Chem. A, 119, 4418-4432, https://doi.org/10.1021/jp509534k, 2015.

Manion, J. A., Huie, R. E., Levin, R. D., Burgess Jr., D. R., Orkin, V. L., Tsang, W., McGivern, W. S., Hudgens, J. W., Knyazev, V. D., Atkinson, D. B., Chai, E., Tereza, A. M., Lin, C.-Y., Allison, T. C., Mallard, W. G., Westley, F., Herron, J. T., Hampson, R. F., and Frizzell, D. H.: NIST Chemical Kinetics Database, NIST Standard Reference Database 17, Version 7.0 (Web Version), Release 1.6.8, Data version 2015.09, National Institute of Standards and Technology, Gaithersburg, Maryland, 20899-8320, available at: http://kinetics.nist.gov/ (last access: 13 May 2020), 2015.

Melaas, E. K., Wang, J. A., Miller, D. L., and Friedl, M. A.: Interactions between urban vegetation and surface urban heat islands: a case study in the Boston metropolitan region, Environ. Res. Lett., 11, 054020, https://doi.org/10.1088/17489326/11/5/054020, 2016.

Middlebrook, A. M., Bahreini, R., Jimenez, J. L., and Canagaratna, M. R.: Evaluation of Composition-Dependent Collection Efficiencies for the Aerodyne Aerosol Mass Spectrometer using Field Data, Aerosol. Sci. Technol., 46, 258-271, 2012.

Nah, T., Sanchez, J., Boyd, C. M., and Ng, N. L.: Photochemical Aging of $\alpha$-pinene and $\beta$-pinene Secondary Organic Aerosol formed from Nitrate Radical Oxidation, Environ. Sci. Technol., 50, 222-231, https://doi.org/10.1021/acs.est.5b04594, 2016.

Ng, N. L., Brown, S. S., Archibald, A. T., Atlas, E., Cohen, R. C., Crowley, J. N., Day, D. A., Donahue, N. M., Fry, J. L., Fuchs, H., Griffin, R. J., Guzman, M. I., Herrmann, H., Hodzic, A., Iinuma, Y., Jimenez, J. L., Kiendler-Scharr, A., Lee, B. H., Luecken, D. J., Mao, J., McLaren, R., Mutzel, A., Osthoff, H. D., Ouyang, B., Picquet-Varrault, B., Platt, U., Pye, H. O. T., Rudich, Y., Schwantes, R. H., Shiraiwa, M., Stutz, J., Thornton, J. A., Tilgner, A., Williams, B. J., and Zaveri, R. A.: Nitrate radicals and biogenic volatile organic compounds: oxidation, mechanisms, and organic aerosol, Atmos. Chem. Phys., 17, 2103-2162, https://doi.org/10.5194/acp-17-2103-2017, 2017.

Orlando, J. J. and Tyndall, G. S.: Laboratory studies of organic peroxy radical chemistry: an overview with emphasis on recent is- sues of atmospheric significance, Chem. Soc. Rev., 41, 62946317, https://doi.org/10.1039/C2CS35166H, 2012.

Orphal, J., Fellows, C. E., and Flaud, P.-M.: The visible absorption spectrum of $\mathrm{NO}_{3}$ measured by high-resolution Fourier transform spectroscopy, J. Geophys. Res.-Atmos., 108, 4077, https://doi.org/10.1029/2002JD002489, 2003.

Palm, B. B., Campuzano-Jost, P., Day, D. A., Ortega, A. M., Fry, J. L., Brown, S. S., Zarzana, K. J., Dube, W., Wagner, N. L., Draper, D. C., Kaser, L., Jud, W., Karl, T., Hansel, A., GutiérrezMontes, C., and Jimenez, J. L.: Secondary organic aerosol formation from in situ $\mathrm{OH}, \mathrm{O}_{3}$, and $\mathrm{NO}_{3}$ oxidation of ambient forest air in an oxidation flow reactor, Atmos. Chem. Phys., 17, 53315354, https://doi.org/10.5194/acp-17-5331-2017, 2017.

Peng, Z. and Jimenez, J. L.: Modeling of the chemistry in oxidation flow reactors with high initial NO, Atmos. Chem. Phys., 17, 11991-12010, https://doi.org/10.5194/acp-17-11991-2017, 2017.

Peng, Z. and Jimenez, J. L.: KinSim: A Research-Grade, UserFriendly, Visual Kinetics Simulator for Chemical-Kinetics and Environmental-Chemistry Teaching, J. Chem. Educ., 96, 806811, https://doi.org/10.1021/acs.jchemed.9b00033, 2019.

Peng, Z. and Jimenez, J.: Downloadable KinSim cases and mechanisms, available at: https://tinyurl.com/kinsim-cases\#bookmark= kix.6zu8zdwq2lce, last access: 13 May 2020.

Peng, Z., Day, D. A., Stark, H., Li, R., Lee-Taylor, J., Palm, B. B., Brune, W. H., and Jimenez, J. L.: $\mathrm{HO}_{\mathrm{x}}$ radical chemistry in oxidation flow reactors with low-pressure mercury lamps systematically examined by modeling, Atmos. Meas. Tech., 8, 4863-4890, https://doi.org/10.5194/amt-8-4863-2015, 2015.

Peng, Z., Palm, B. B., Day, D. A., Talukdar, R. K., Hu, W., Lambe, A. T., Brune, W. H., and Jimenez, J. L.: Model Evaluation of New Techniques for Maintaining High-NO Conditions in Oxidation Flow Reactors for the Study of OH-Initiated Atmospheric Chemistry, ACS Earth Space Chem., 2, 72-86, https://doi.org/10.1021/acsearthspacechem.7b00070, 2018.

Peng, Z., Lee-Taylor, J., Orlando, J. J., Tyndall, G. S., and Jimenez, J. L.: Organic peroxy radical chemistry in oxidation flow reactors and environmental chambers and their atmospheric relevance, Atmos. Chem. Phys., 19, 813-834, https://doi.org/10.5194/acp19-813-2019, 2019.

Platz, J., Nielsen, O. J., Wallington, T. J., Ball, J. C., Hurley, M. D., Straccia, A. M., Schneider, W. F., and Sehested, J.: Atmospheric Chemistry of the Phenoxy Radical, $\mathrm{C}_{6} \mathrm{H}_{5} \mathrm{O}$ : UV Spectrum and Kinetics of its Reaction with $\mathrm{NO}, \mathrm{NO}_{2}$ and $\mathrm{O}_{2}$, J. Phys. Chem. A, 102, 7964-7974, https://doi.org/10.1021/jp9822211, 1998.

Rudich, Y., Talukdar, R. K., Imamura, T., Fox, R. W., and Ravishankara, A. R.: Uptake of $\mathrm{NO}_{3}$ on KI solutions: rate coefficient for the $\mathrm{NO}_{3}+$ I-reaction and gas-phase diffusion coefficients for $\mathrm{NO}_{3}$, Chem. Phys. Lett., 261, 467-473, 1996.

Saunders, S. M., Jenkin, M. E., Derwent, R. G., and Pilling, M. J.: Protocol for the development of the Master Chemical Mechanism, MCM v3 (Part A): tropospheric degradation of nonaromatic volatile organic compounds, Atmos. Chem. Phys., 3, 161-180, https://doi.org/10.5194/acp-3-161-2003, 2003.

Short, K. C.: Spatial wildfire occurrence data for the United States, 1992-2015, 4th Edition, https://doi.org/10.2737/RDS2013-0009.4, 2017.

Stutz, J., Alicke, B., Ackermann, R., Geyer, A., White, A., and Williams, E.: Vertical profiles of $\mathrm{NO}_{3}, \mathrm{~N}_{2} \mathrm{O}_{5}, \mathrm{O}_{3}$, and $\mathrm{NO}_{x}$ 
in the nocturnal boundary layer: 1. Observations during the Texas Air Quality Study 2000, J. Geophys. Res., 109, D12306, https://doi.org/10.1029/2003jd004209, 2004.

Vandaele, A. C., Hermans, C., Simon, P. C., Carleer, M., Colin, R., Fally, S., Mérienne, M. F., Jenouvrier, A., and Coquart, B.: Measurements of the $\mathrm{NO}_{2}$ absorption cross-section from $42000 \mathrm{~cm}^{-1}$ to $10000 \mathrm{~cm}^{-1}(238-1000 \mathrm{~nm})$ at $220 \mathrm{~K}$ and 294 K., J. Quant. Spectrosc. Radiat. Transf., 59, 171-184, https://doi.org/10.1016/S0022-4073(97)00168-4, 1998.

Venables, D. S., Gherman, T., Orphal, J., Wenger, J. C., and Ruth, A. A.: High Sensitivity in Situ Monitoring of $\mathrm{NO}_{3}$ in an Atmospheric Simulation Chamber Using Incoherent Broadband Cavity-Enhanced Absorption Spectroscopy, Environ. Sci. Technol., 40, 6758-6763, https://doi.org/10.1021/es061076j, 2006.

Voigt, S., Orphal, J., Bogumil, K., and Burrows, J. P.: The temperature dependence (203-293 K) of the absorption cross sections of $\mathrm{O}_{3}$ in the $230-850 \mathrm{~nm}$ region measured by Fourier-transform spectroscopy, J. Photoch. Photobio. A, 143, 1-9, 2001.

Wagner, C., Hanisch, F., Holmes, N., de Coninck, H., Schuster, G., and Crowley, J. N.: The interaction of $\mathrm{N}_{2} \mathrm{O}_{5}$ with mineral dust: aerosol flow tube and Knudsen reactor studies, Atmos. Chem. Phys., 8, 91-109, https://doi.org/10.5194/acp-8-91-2008, 2008.
Warneck, P. and Williams, J.: The Atmospheric Chemist's Companion, Springer, Dordrecht, https://doi.org/10.1007/978-94-0072275-0, 2012.

Wayne, R. P., Barnes, I., Biggs, P., Burrows, J. P., Canosa-Mas, C. E., Hjorth, J., Le Bras, G., Moortgat, G. K., Perner, D., Poulet, G., Restelli, G., and Sidebottom, H.: The nitrate radical: physics, chemistry, and the atmosphere, Atmos. Environ. A, 25, 1-203, 1991.

Wood, E. C., Wooldridge, P. J., Freese, J. H., Albrecht, T., and Cohen, R. C.: Prototype for In Situ Detection of Atmospheric $\mathrm{NO}_{3}$ and $\mathrm{N}_{2} \mathrm{O}_{5}$ via Laser-Induced Fluorescence, Environ. Sci. Technol., 37, 5732-5738, https://doi.org/10.1021/es034507w, 2003.

$\mathrm{Xu}$, W., Lambe, A., Silva, P., Hu, W., Onasch, T., Williams, L., Croteau, P., Zhang, X., Renbaum-Wolff, L., Fortner, E., Jimenez, J. L., Jayne, J., Worsnop, D., and Canagaratna, M.: Laboratory evaluation of species-dependent relative ionization efficiencies in the Aerodyne Aerosol Mass Spectrometer, Aerosol. Sci. Technol., 52, 626-641, https://doi.org/10.1080/02786826.2018.1439570, 2018. 